\title{
State Transmission Infrastructure Authorities: The Story So Far
}

Subcontract Report NREL/SR-500-43146

May 2008

\section{December 2007 - December 2008}

K. Porter and S. Fink

Exeter Associates, Inc.

Columbia, Maryland
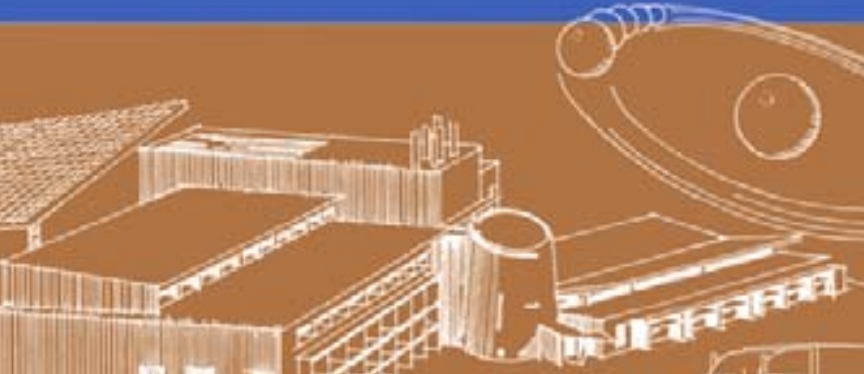


\section{State Transmission Infrastructure Authorities: The Story So Far}

\section{December 2007 - December 2008}

K. Porter and S. Fink

Exeter Associates, Inc.

Columbia, Maryland

NREL Technical Monitor: David Corbus

Prepared under Subcontract No. LAM-8-77548-01

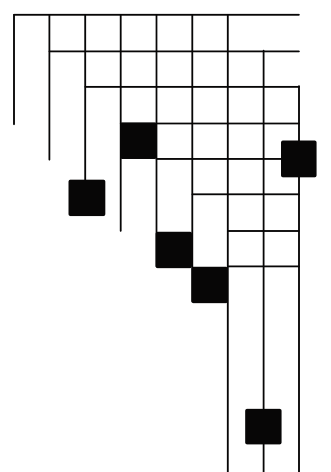




\section{NOTICE}

This report was prepared as an account of work sponsored by an agency of the United States government. Neither the United States government nor any agency thereof, nor any of their employees, makes any warranty, express or implied, or assumes any legal liability or responsibility for the accuracy, completeness, or usefulness of any information, apparatus, product, or process disclosed, or represents that its use would not infringe privately owned rights. Reference herein to any specific commercial product, process, or service by trade name, trademark, manufacturer, or otherwise does not necessarily constitute or imply its endorsement, recommendation, or favoring by the United States government or any agency thereof. The views and opinions of authors expressed herein do not necessarily state or reflect those of the United States government or any agency thereof.

Available electronically at http://www.osti.gov/bridge

Available for a processing fee to U.S. Department of Energy and its contractors, in paper, from:

U.S. Department of Energy

Office of Scientific and Technical Information

P.O. Box 62

Oak Ridge, TN 37831-0062

phone: 865.576 .8401

fax: 865.576 .5728

email: mailto:reports@adonis.osti.gov

Available for sale to the public, in paper, from:

U.S. Department of Commerce

National Technical Information Service

5285 Port Royal Road

Springfield, VA 22161

phone: 800.553 .6847

fax: 703.605.6900

email: orders@ntis.fedworld.gov

online ordering: http://www.ntis.gov/ordering.htm

This publication received minimal editorial review at NREL 


\section{TABLE OF CONTENTS}

PAGE

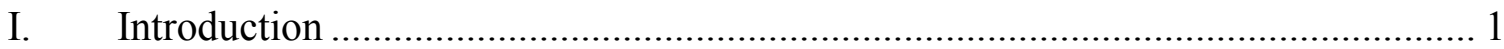

II. Characteristics of State Infrastructure Authorities ……....................................... 2

Project Development and Ownership ................................................................ 3

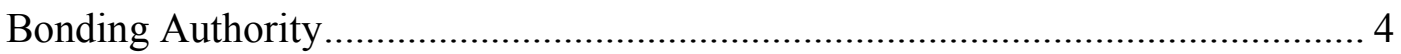

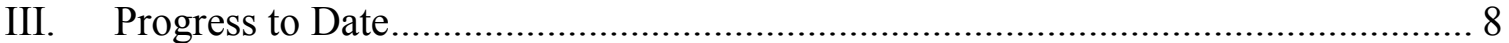

IV. Implications for Wind Power ....................................................................... 14

V. Issues Facing State Infrastructure Authorities.................................................. 15

VI. Conclusion and Recommendations ............................................................... 17

\section{LIST OF TABLES}

PAGE

1 Characteristics of State Infrastructure Authorities ................................................ 6

2 Potential Large Transmission Projects that State Transmission Infrastructure Authorities May be Involved In .................................................................... 14

\section{LISTS OF FIGURES}

PAGE

1 States with Transmission Infrastructure Authorities ............................................. 3

2 Proposed Kansas Transmission Projects ........................................................... 10

3 Wyoming-Colorado Intertie Transmission Project ………………......................... 11

4 TransWest Express/Gateway South Transmission Projects .................................... 12

$5 \quad$ High Plains Express Transmission Project........................................................... 13 


\section{APPENDIX}

\section{PAGE}

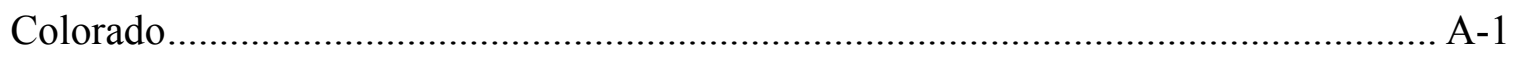

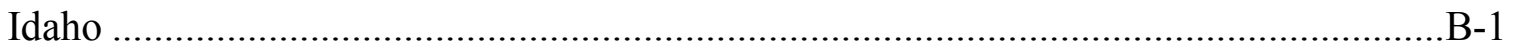

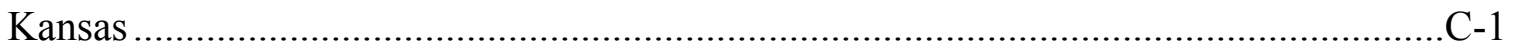

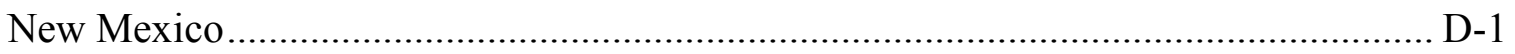

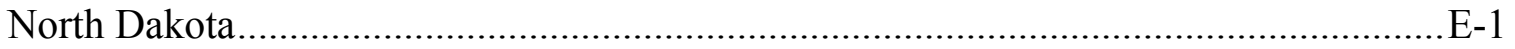

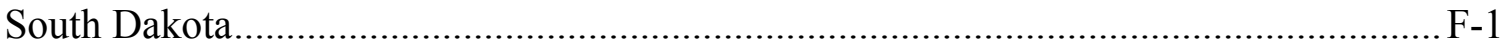

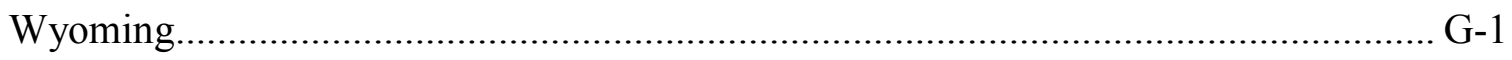




\section{Acknowledgments}

The National Renewable Energy Laboratory's Wind Technologies Program funded the research that went into this project. The authors thank Brian Parsons and David Corbus of the National Renewable Energy Laboratory for supporting this work.

Five of the seven state transmission infrastructure authorities agreed to be interviewed for this report. They also graciously answered several questions that arose during the course of this project and reviewed initial drafts of the report and of the state profiles. We thank the representatives of the state transmission infrastructure authorities for their assistance. We also thank Erik Ela and Lynn Coles of the National Renewable Energy Laboratory, and Andrew Mills and Ryan Wiser of the Ernest Orlando Lawrence Berkeley National Laboratory for their review comments. Finally, the authors thank Bruce Green of the National Renewable Energy Laboratory for his editorial assistance. 


\section{Introduction}

Increasing recognition of the need for more transmission and the desire to access new generating resources has led to an increased emphasis on transmission planning and development. The Western Governors' Association's Clean and Diversified Energy Advisory Committee identified transmission as a critical element in achieving their goal of securing $30 \mathrm{GW}$ of clean energy by 2015. ${ }^{\mathrm{a}}$ Furthermore, the Federal Energy Regulatory Commission (FERC) made transmission planning an important part of Order 890, calling upon all FERC-regulated transmission providers to file their transmission planning practices at FERC. ${ }^{b}$ The North American Electric Reliability Corporation recently stated that more transmission is needed to ease the strain on the existing transmission system, to make up for past under-investment in transmission, and to better incorporate renewable energy technologies such as wind energy. ${ }^{c}$

Increasing growth in the development of renewable energy resources and the interest in encouraging more renewable energy development is also occurring. Over 5,000 MW of wind came online in the United States in 2007, bringing total U.S. installed wind capacity to over 16,800 MW. ${ }^{\mathrm{d}}$ The Geothermal Energy Association reported that 2,850 MW of geothermal capacity was in operation as of 2007 , with another $2,455 \mathrm{MW}$ in various stages of development. ${ }^{\mathrm{e}}$ The solar energy industry is also growing, with the first large-scale utility solar thermal project in nearly 20 years coming online in Nevada in 2007. Another 22,000 MW of solar energy projects are in the California Independent System Operator's interconnection queue. ${ }^{\mathrm{f}}$

Recently, seven states have created transmission infrastructure authorities to help facilitate, enable, and perhaps finance new transmission facilities to access new energy resources including renewable energy. In general, these transmission infrastructure authorities are modeled after state finance or development authorities and are empowered to issue bonds in support of transmission (and, in some cases, generation and distribution) facilities. These state transmission infrastructure authorities do not rely on the full faith and credit of the state in issuing bonds. Instead, the bonds issued will likely be revenue bonds that must be secured by a revenue stream from the transmission investment, such as usage charges or lease payments. As a general matter, the bonds are exempt from state taxes but are still subject to federal taxes. While the focus and main purpose for the creation of these infrastructure authorities is to advance transmission

\footnotetext{
a Western Governors' Association. (June 2006). Clean Energy, A Strong Economy and A Healthy Environment. Report of the Clean and Diversified Energy Advisory Committee to the Western Governors Association. http://www.westgov.org/wga/meetings/am2006/CDEAC06.pdf. (Accessed April 4, 2008).

${ }^{\mathrm{b}}$ Federal Energy Regulatory Commission. (February 2007). Order No. 890, 18 CFR Parts 35 and 37. http://www.ferc.gov/whats-new/comm-meet/2007/021507/E-1.pdf. (Accessed February 5, 2008).

${ }^{\mathrm{c}}$ North American Electric Reliability Corporation. (October 2007). 2007 Long-Term Reliability Assessment. ftp://ftp.nerc.com/pub/sys/all_updl/docs/pubs/LTRA2007.pdf. (Accessed February 5, 2008).

d American Wind Energy Association. (January 2007). AWEA 2007 Market Report. http://www.awea.org/projects/pdf/Market_Report_Jan08.pdf. (Accessed April 3, 2008).

${ }^{\mathrm{e}}$ Geothermal Energy Association. (May 2007). Update on US Geothermal Power Production and Development. http://www.geo-

energy.org/publications/reports/May2007GEAUpdateonUSGeothermalPowerProductionandDevelopment.pdf. (Accessed April 3, 2008).

${ }_{\mathrm{f}}$ Internal estimate prepared by Exeter Associates. The California ISO interconnection queue can be viewed at http://www.caiso.com/14e9/14e9ddda1ebf0.pdf.
} 
development, some of them have been granted the ability to pursue generation and/or distribution projects as well. Most of the authorities have also been given the ability to exercise the power of eminent domain with respect to project siting within their jurisdictions. State transmission infrastructure authorities are also serving a coordinating function and bringing much needed attention to transmission development by acting as early incubators and catalysts for transmission projects. Nearly all the state transmission infrastructure authorities were formed to tap into extensive in-state resources such as wind and coal for export to out-of-state load centers.

States with transmission infrastructure authorities are located in regions with some of the best wind potential in the country. By national ranking according to wind resource quality, North Dakota is rated $1^{\text {st }}$; Kansas $3^{\text {rd }}$; South Dakota $4^{\text {th }}$; Wyoming $7^{\text {th }}$; Colorado $11^{\text {th }}$; New Mexico $12^{\text {th }}$; and Idaho $13^{\text {th }}$. Except for Colorado and Kansas, none of the states with transmission infrastructure authorities are in the top ten of states with installed wind capacity, suggesting state transmission infrastructure authorities could perhaps help their states unlock wind potential through upgrading or adding transmission. ${ }^{\mathrm{h}}$

This report examines the status and future direction of state transmission infrastructure authorities. The report begins by summarizing common characteristics of state transmission infrastructure authorities, goes on to discuss some transmission projects that state infrastructure authorities are involved in and then outlines common issues the state infrastructure authorities have faced. The report closes with some recommendations. An appendix profiling each of the state infrastructure authorities is at the end of this report.

\section{Characteristics of State Infrastructure Authorities}

Wyoming was the first state to establish a transmission infrastructure authority when the Wyoming Infrastructure Authority (WIA) was created in 2004. The WIA was modeled after the Wyoming Pipeline Authority, which has been successful in facilitating natural gas pipeline development in the state. Other states have followed suit, resulting in the creation of the South Dakota Energy Infrastructure Authority (SDEIA), the North Dakota Transmission Authority (NDTA), the Idaho Energy Resources Authority (IERA), and the Kansas Electric Transmission Authority (KETA) in 2005, then more recently, the New Mexico Renewable Energy Transmission Authority (RETA) and the Colorado Clean Energy Development Authority (CEDA) in 2007 (see Figure 1).

\footnotetext{
${ }^{\mathrm{g}}$ American Wind Energy Association. Wind Energy: An Untapped Resource. http://www.awea.org/pubs/factsheets/Wind_Energy_An_Untapped_Resource.pdf. (Accessed February 12, 2008). $\mathrm{h}$ American Wind Energy Association. U.S. Wind Energy Projects. http://www.awea.org/projects (Accessed February 12, 2008).
} 


\section{Figure 1. States with Transmission Infrastructure Authorities}

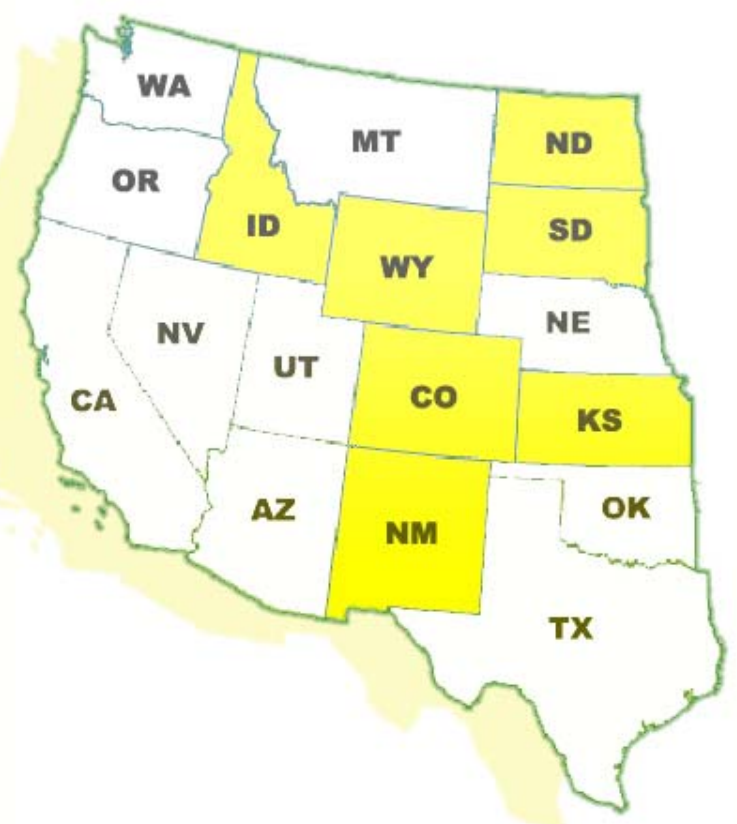

As a rule, these states are rich in potential generation resources and generally have a desire to develop those resources for export to other states. Wyoming has significant wind, natural gas, and coal resources that it would like to develop and transmit to load centers in the West. South Dakota and North Dakota also have coal and wind resources that they would like to develop and transmit into load centers in the Midwest. New Mexico and Colorado have created their authorities primarily for the purpose of developing and marketing their renewable energy resources. Kansas is situated between the Western and Eastern Interconnections, potentially allowing the state the opportunity to market its wind and coal resources to both interconnections. By contrast, Idaho is a net energy importer and the transmission infrastructure authority was mainly created for the purpose of adding or accessing new generating resources to help enhance the state's energy reliability.

\section{Project Development and Ownership}

Differences exist among the state transmission infrastructure authorities with respect to the types of projects that are eligible and each authority's ability to construct, own, and/or operate facilities. KETA, NDTA, and RETA are only allowed to engage in transmission development, although RETA may also finance electricity storage facilities. RETA has a requirement that the transmission projects it gets involved with are expected to source at least 30 percent of the energy from renewables. CEDA can only engage in clean energy projects but, in addition to transmission, can finance generation, transportation, storage, and equipment manufacturing facilities. CEDA's scope also includes clean fuel projects such as biodiesel and ethanol, and 
potentially clean coal technologies. ${ }^{\text {i }}$ IERA can develop generation, transmission, or distribution projects, but it must partner with a utility or independent power producer. WIA and SDEIA can become involved with both generation and transmission; however, both authorities have decided to focus initially on transmission, viewing it as the most pressing issue.

State transmission infrastructure authorities have different restrictions on owning and operating transmission facilities. CEDA is a financing authority only and cannot own or operate any facilities. NDTA, SDEIA, and WIA can construct, obtain, own, and operate any eligible facilities. However, NDTA and SDEIA are required to divest those facilities at the first economically practical opportunity, and WIA has been directed to review, at least every three years, the feasibility of disposing of facilities it holds. RETA can only own facilities as long as they are leased to other entities, although there is no mandatory divestiture requirement. IERA develops facilities on behalf of or in partnership with utilities or independent power producers, with the decision on subsequent project operation resting with the utility or independent power producer. These entities can request that IERA operate the facility on their behalf. KETA is the only authority without limitations or conditions on owning transmission infrastructure facilities and may choose to construct or acquire eligible facilities and own them in perpetuity. KETA is only restricted with respect to operating transmission facilities and must contract out facility operations to a qualified entity.

State transmission infrastructure authorities typically are required to give public notice in developing a project, and allow market participants to step in if they wish. KETA, RETA, NDTA, and WIA must all publicly advertise their intent to develop a project and grant other entities the ability to come forward and assume the project. The Kansas, New Mexico, and Wyoming transmission infrastructure authorities may resume project development themselves if the other entity does not make progress within a set period of time (180 days for KETA and WIA, 12 months for RETA). NDTA may assess proposals from other market participants and may continue with the project itself if NDTA determines that doing so is in the public interest. CEDA and IERA do not act as independent developers and therefore have no public notice requirement. CEDA's role is a project financer, and IERA works only in partnership with qualified utilities or Independent Power Producers (IPP). SDEIA also has no specific notice requirement for projects.

\section{Bonding Authority}

All of the authorities are created as instrumentalities of the state and can issue revenue bonds. As the authorities are not agents of the state, these bonds are liabilities of the authorities only and do not constitute liabilities of the respective states. The authorities in Idaho, New Mexico, Wyoming, and Kansas can issue bonds at their own discretion through resolutions of their boards, although the Kansas Finance Authority issues the bonds on KETA's behalf. South

\footnotetext{
${ }^{\mathrm{i}}$ CEDA has been directed to convene an advisory panel that will make recommendations on whether hydroelectric power should be included under clean energy; whether and what restrictions should be adopted for biomass; and whether integrated gasification combined cycle generation facilities or other clean coal technologies with carbon sequestration should be considered clean energy projects. CEDA is to convene the panel when sufficient funding has been received from gifts, grants, donations, or project fees.
} 
Dakota requires legislative authorization for the SDEIA to issue bonds. Colorado also requires legislative authorization, although CEDA has pre-authorized approval to issue up to $\$ 40$ million in bonds annually for transmission for wind projects and up to $\$ 25$ million in bonds annually for solar projects. Voter approval of CEDA bonds may be necessary if CEDA is unable to realize sufficient revenues to cover the bond payments, unless the bond payments are secured by a thirdparty financing agreement, a reserve fund, or by a mortgage on the facilities. NDTA is part of the North Dakota Industrial Commission and bond issuances are done through the Industrial Commission.

All the authorities are expected to be financially self-supporting in the long term with revenues arising from the financial returns from completed projects. The authorities have different limits as to the amount of bonds they may issue. WIA has a $\$ 1$ billion bonding cap for bonds issued for private sector projects but no limit to bonding for WIA-developed facilities. SDEIA has a total bonding cap set at $\$ 1$ billion, and NDTA's is set at $\$ 800$ million. IERA, KETA, and RETA do not at this time have a cap. CEDA also does not have a cap, but the annual bond payments cannot exceed $\$ 8$ million. Table 1 provides the characteristics of the various state infrastructure authorities. 
Table 1. Characteristics of State Infrastructure Authorities

\begin{tabular}{|c|c|c|c|c|c|c|}
\hline & $\begin{array}{l}\text { Bonding } \\
\text { Authority }\end{array}$ & $\begin{array}{l}\text { Eligible } \\
\text { Projects }\end{array}$ & $\begin{array}{l}\text { Project } \\
\text { Ownership, } \\
\text { Operation, } \\
\text { and Cost } \\
\text { Recovery }\end{array}$ & Public Notice & $\begin{array}{l}\text { In-state } \\
\text { Bylaws and } \\
\text { Eminent } \\
\text { Domain }\end{array}$ & $\begin{array}{l}\text { Operational } \\
\text { Funding }\end{array}$ \\
\hline $\begin{array}{l}\text { Colorado } \\
\text { Clean Energy } \\
\text { Development } \\
\text { Authority }\end{array}$ & $\begin{array}{l}\text { Can issue } \\
\text { revenue bonds } \\
\text { through } \\
\text { resolutions of } \\
\text { the board but } \\
\text { need to be } \\
\text { approved by } \\
\text { legislature. } \\
\text { Bonds pre- } \\
\text { authorized for } \\
\text { up to } \$ 40 \\
\text { million } \\
\text { annually for } \\
\text { wind projects } \\
\text { and up to } \$ 25 \\
\text { million for } \\
\text { solar energy } \\
\text { projects. No } \\
\text { cap, but bond } \\
\text { annual } \\
\text { payments } \\
\text { cannot exceed } \\
\$ 8 \text { million. }\end{array}$ & $\begin{array}{l}\text { Generation, } \\
\text { transportation, } \\
\text { transmission, } \\
\text { equipment } \\
\text { manufacturing, } \\
\text { and storage of } \\
\text { clean energy, } \\
\text { or non-clean if } \\
\text { will be clean } \\
\text { within } 5 \text { years. }\end{array}$ & $\begin{array}{l}\text { Can only } \\
\text { provide } \\
\text { project } \\
\text { financing } \\
\text { and } \\
\text { development } \\
\text { support; } \\
\text { cannot own } \\
\text { or operate. }\end{array}$ & $\begin{array}{l}\text { No public } \\
\text { notice } \\
\text { requirement. }\end{array}$ & $\begin{array}{l}\text { Can adopt } \\
\text { and amend } \\
\text { bylaws and } \\
\text { exercise any } \\
\text { authority } \\
\text { necessary to } \\
\text { achieve its } \\
\text { objectives. }\end{array}$ & $\begin{array}{l}\text { Can receive } \\
\text { grants, loans, } \\
\text { contributions, } \\
\text { and other } \\
\text { financial aid. } \\
\text { Is receiving } \\
\text { some start-up } \\
\text { support from } \\
\text { the Colorado } \\
\text { Clean Energy } \\
\text { Fund. }\end{array}$ \\
\hline $\begin{array}{l}\text { Idaho Energy } \\
\text { Resources } \\
\text { Authority }\end{array}$ & $\begin{array}{l}\text { Can issue } \\
\text { revenue bonds } \\
\text { through } \\
\text { resolutions of } \\
\text { the board. No } \\
\text { cap has been } \\
\text { set. }\end{array}$ & $\begin{array}{l}\text { Generation, } \\
\text { transmission, } \\
\text { and } \\
\text { distribution } \\
\text { facilities but } \\
\text { only in } \\
\text { partnership } \\
\text { with a utility } \\
\text { or IPP. }\end{array}$ & $\begin{array}{l}\text { Ownership } \\
\text { allowed with } \\
\text { no } \\
\text { divestiture } \\
\text { requirement } \\
\text { unless the } \\
\text { utility or IPP } \\
\text { requests it. } \\
\text { Utilities can } \\
\text { request cost } \\
\text { recovery } \\
\text { through rates } \\
\text { from the } \\
\text { Idaho PUC. }\end{array}$ & $\begin{array}{l}\text { No public } \\
\text { notice } \\
\text { requirement. }\end{array}$ & $\begin{array}{l}\text { Can adopt } \\
\text { bylaws. Can } \\
\text { exercise } \\
\text { eminent } \\
\text { domain with } \\
\text { respect to } \\
\text { generation } \\
\text { and } \\
\text { transmission } \\
\text { projects. }\end{array}$ & $\begin{array}{l}\text { Can receive } \\
\text { grants, loans, } \\
\text { contributions, } \\
\text { and other } \\
\text { financial aid. } \\
\text { Received } \\
\$ 50,000 \text { start- } \\
\text { up funds from } \\
\text { Idaho } \\
\text { Consumer- } \\
\text { Owned } \\
\text { Utilities } \\
\text { Association in } \\
\text { 2006. }\end{array}$ \\
\hline
\end{tabular}




\begin{tabular}{|c|c|c|c|c|c|c|}
\hline & $\begin{array}{l}\text { Bonding } \\
\text { Authority }\end{array}$ & $\begin{array}{l}\text { Eligible } \\
\text { Projects }\end{array}$ & $\begin{array}{l}\text { Project } \\
\text { Ownership, } \\
\text { Operation, } \\
\text { and Cost } \\
\text { Recovery } \\
\end{array}$ & Public Notice & $\begin{array}{l}\text { In-state } \\
\text { Bylaws and } \\
\text { Eminent } \\
\text { Domain }\end{array}$ & $\begin{array}{l}\text { Operational } \\
\text { Funding }\end{array}$ \\
\hline $\begin{array}{l}\text { Kansas } \\
\text { Electric } \\
\text { Transmission } \\
\text { Authority }\end{array}$ & $\begin{array}{l}\text { Contracts with } \\
\text { the Kansas } \\
\text { Development } \\
\text { Finance } \\
\text { Authority to } \\
\text { issue revenue } \\
\text { bonds. No cap } \\
\text { has been set. }\end{array}$ & $\begin{array}{l}\text { Transmission } \\
\text { and related } \\
\text { supporting } \\
\text { infrastructure } \\
\text { only. For out- } \\
\text { of-state } \\
\text { facilities, at } \\
\text { least } 51 \% \text { of } \\
\text { the project } \\
\text { cost must be } \\
\text { realized in } \\
\text { Kansas. }\end{array}$ & $\begin{array}{l}\text { Ownership } \\
\text { allowed with } \\
\text { no } \\
\text { divestiture } \\
\text { requirement, } \\
\text { but facility } \\
\text { operation } \\
\text { must be } \\
\text { contracted } \\
\text { out. Can } \\
\text { recover costs } \\
\text { through SPP } \\
\text { and in-state } \\
\text { tariffs. }\end{array}$ & $\begin{array}{l}90 \text { days public } \\
\text { notice of intent } \\
\text { to develop. If } \\
\text { private } \\
\text { developer } \\
\text { expresses intent } \\
\text { to develop } \\
\text { project, it has } \\
180 \text { days to } \\
\text { show progress } \\
\text { or KETA can } \\
\text { proceed with } \\
\text { the project. }\end{array}$ & $\begin{array}{l}\text { Can adopt } \\
\text { bylaws and } \\
\text { use power } \\
\text { of eminent } \\
\text { domain } \\
\text { subject to } \\
\text { Corporate } \\
\text { Commission } \\
\text { regulations. }\end{array}$ & $\begin{array}{l}\text { Can receive } \\
\text { grants, loans, } \\
\text { contributions, } \\
\text { and other } \\
\text { financial aid. } \\
\text { Legislature } \\
\text { appropriated } \\
\$ 170,000 \text { for } \\
2007 \text { and } 2008 \\
\text { for operations } \\
\text { from the } \\
\text { Public Service } \\
\text { Regulatory } \\
\text { Commission } \\
\text { and } \\
\text { established a } \\
\$ 1 \text { million } \\
\text { contingency } \\
\text { fund for } \\
\text { project } \\
\text { support. }\end{array}$ \\
\hline $\begin{array}{l}\text { New Mexico } \\
\text { Renewable } \\
\text { Energy } \\
\text { Transmission } \\
\text { Authority }\end{array}$ & $\begin{array}{l}\text { Can issue } \\
\text { revenue bonds } \\
\text { through } \\
\text { resolutions of } \\
\text { the board. No } \\
\text { cap set. }\end{array}$ & $\begin{array}{l}\text { Transmission } \\
\text { projects with } \\
\text { at least } 30 \% \\
\text { from } \\
\text { renewable } \\
\text { energy and } \\
\text { electric storage } \\
\text { projects. }\end{array}$ & $\begin{array}{l}\text { Not allowed } \\
\text { to own or } \\
\text { control } \\
\text { facilities } \\
\text { unless they } \\
\text { are leased to } \\
\text { other } \\
\text { entities. } \\
\text { Utilities } \\
\text { involved in } \\
\text { projects can } \\
\text { recover costs } \\
\text { through } \\
\text { rates. }\end{array}$ & $\begin{array}{l}\text { Must give } 90 \\
\text { days notice of } \\
\text { intent to } \\
\text { develop. Other } \\
\text { developer has } \\
12 \text { months to } \\
\text { show progress } \\
\text { on project or } \\
\text { RETA may } \\
\text { reacquire. }\end{array}$ & $\begin{array}{l}\text { Can } \\
\text { exercise } \\
\text { power of } \\
\text { eminent } \\
\text { domain. }\end{array}$ & $\begin{array}{l}\text { Can receive } \\
\text { grants, loans, } \\
\text { contributions, } \\
\text { and other } \\
\text { financial aid. } \\
\text { Has received } \\
\$ 1 \text { million in } \\
\text { start-up } \\
\text { funding from } \\
\text { legislature. }\end{array}$ \\
\hline $\begin{array}{l}\text { North Dakota } \\
\text { Transmission } \\
\text { Authority }\end{array}$ & $\begin{array}{l}\text { Can issue } \\
\text { revenue bonds } \\
\text { with } \\
\text { authorization } \\
\text { from the } \\
\text { North Dakota } \\
\text { Industrial } \\
\text { Commission. } \\
\text { Cap set at } \\
\$ 800 \text { million. }\end{array}$ & $\begin{array}{l}\text { Transmission } \\
\text { facilities only. }\end{array}$ & $\begin{array}{l}\text { Ownership } \\
\text { allowed but } \\
\text { must divest } \\
\text { as soon as } \\
\text { economically } \\
\text { practical. } \\
\text { Can establish } \\
\text { rates, fees, or } \\
\text { tariffs } \\
\text { through } \\
\text { PSC. }\end{array}$ & $\begin{array}{l}\text { Must give } 180 \\
\text { days notice of } \\
\text { intent to } \\
\text { develop and } \\
\text { may still } \\
\text { proceed even if } \\
\text { another entity } \\
\text { notifies intent to } \\
\text { take on project } \\
\text { if NDTA } \\
\text { determines that } \\
\text { doing so is in } \\
\text { the public } \\
\text { interest. }\end{array}$ & $\begin{array}{l}\text { Can } \\
\text { investigate, } \\
\text { plan, } \\
\text { prioritize, } \\
\text { and propose } \\
\text { electric } \\
\text { transmission } \\
\text { corridors. }\end{array}$ & $\begin{array}{l}\text { Part of North } \\
\text { Dakota } \\
\text { Industrial } \\
\text { Commission } \\
\text { and works } \\
\text { under its } \\
\text { budget. }\end{array}$ \\
\hline
\end{tabular}




\begin{tabular}{|c|c|c|c|c|c|c|}
\hline & $\begin{array}{l}\text { Bonding } \\
\text { Authority }\end{array}$ & $\begin{array}{l}\text { Eligible } \\
\text { Projects }\end{array}$ & $\begin{array}{l}\text { Project } \\
\text { Ownership, } \\
\text { Operation, } \\
\text { and Cost } \\
\text { Recovery }\end{array}$ & Public Notice & $\begin{array}{l}\text { In-state } \\
\text { Bylaws and } \\
\text { Eminent } \\
\text { Domain }\end{array}$ & $\begin{array}{l}\text { Operational } \\
\text { Funding }\end{array}$ \\
\hline $\begin{array}{l}\text { South Dakota } \\
\text { Energy } \\
\text { Infrastructure } \\
\text { Authority }\end{array}$ & $\begin{array}{l}\text { Can issue } \\
\text { revenue bonds } \\
\text { but must be } \\
\text { approved by } \\
\text { the legislature. } \\
\text { Cap set at } \$ 1 \\
\text { billion. }\end{array}$ & $\begin{array}{l}\text { All energy } \\
\text { production and } \\
\text { transmission } \\
\text { facilities but } \\
\text { has chosen to } \\
\text { focus on } \\
\text { electricity. }\end{array}$ & $\begin{array}{l}\text { Ownership } \\
\text { allowed but } \\
\text { must divest } \\
\text { as soon as } \\
\text { economically } \\
\text { practical. }\end{array}$ & $\begin{array}{l}\text { No project } \\
\text { notice } \\
\text { requirements. }\end{array}$ & $\begin{array}{l}\text { Can } \\
\text { exercise } \\
\text { power of } \\
\text { eminent } \\
\text { domain. }\end{array}$ & $\begin{array}{l}\text { Can receive } \\
\text { grants, loans, } \\
\text { contributions, } \\
\text { and other } \\
\text { financial aid. } \\
\text { Received } \\
\$ 247,000 \text { in } \\
\text { start-up } \\
\text { funding from } \\
\text { the legislature } \\
\text { for } 2006 \text { and } \\
2007 \text {, and } \\
\$ 56,000 \text { for } \\
2008 \text {. }\end{array}$ \\
\hline $\begin{array}{l}\text { Wyoming } \\
\text { Infrastructure } \\
\text { Authority }\end{array}$ & $\begin{array}{l}\text { Can issue } \\
\text { revenue bonds } \\
\text { through } \\
\text { resolutions of } \\
\text { the board. Cap } \\
\text { set at } \$ 1 \\
\text { billion for } \\
\text { separate entity } \\
\text { project } \\
\text { financing. }\end{array}$ & $\begin{array}{l}\text { Transmission } \\
\text { and clean coal } \\
\text { generation } \\
\text { facilities. }\end{array}$ & $\begin{array}{l}\text { Can own and } \\
\text { operate; } \\
\text { policy } \\
\text { preference is } \\
\text { not to. }\end{array}$ & $\begin{array}{l}\text { Must give } 30 \\
\text { days notice of } \\
\text { intent to } \\
\text { develop. Other } \\
\text { developer has } \\
180 \text { days to } \\
\text { show progress } \\
\text { on project or } \\
\text { WIA may } \\
\text { reacquire. }\end{array}$ & $\begin{array}{l}\text { Can } \\
\text { exercise } \\
\text { power of } \\
\text { eminent } \\
\text { domain. }\end{array}$ & $\begin{array}{l}\text { Can receive } \\
\text { loans, grants, } \\
\text { contributions, } \\
\text { and other } \\
\text { financial aid. } \\
\text { Currently has a } \\
\$ 1.6 \text { million } \\
\text { operating } \\
\text { budget and } \\
\$ 10 \text { million } \\
\text { available for } \\
\text { project } \\
\text { development } \\
\text { support. }\end{array}$ \\
\hline
\end{tabular}

\section{Progress to Date}

Considering that the oldest operating state transmission infrastructure authority is just four years old, that two were established in 2007, and that developing large transmission projects can take several years, it is perhaps too soon to make a full evaluation of the impacts of state transmission infrastructure authorities. Nevertheless, state transmission infrastructure authorities are having an impact by facilitating some transmission projects.

KETA has indirectly stimulated at least two proposed transmission projects that were part of the Southwest Power Pool's (SPP) X Plan, despite not being directly involved or issuing any bonds to date. The X Plan is a proposed project that would add new transmission lines in the shape of an X throughout the wind-rich plains of Oklahoma and Kansas. In April 2007, SPP and KETA finalized a study of the feasibility and cost-effectiveness of various line configurations within 
Kansas related to the X Plan. ${ }^{j}$ In May 2007, KETA expressed interest in developing the following X Plan line segments within Kansas: $345 \mathrm{kV}$ lines from Spearville to Reno and from Spearville to Knoll. ${ }^{\mathrm{k}}$ ITC Great Plains subsequently announced its intent to construct and operate a new transmission line with capacity of at least $345 \mathrm{kV}$ from Spearville to a new substation in Comanche County and to an interconnection close to Wichita with a preliminary online date of 2010. ${ }^{1}$ This line is equivalent to the Spearville to Reno segment examined by KETA in its initial feasibility study.

In August 2007, KETA announced its intent to proceed with the $345 \mathrm{kV}$ line from Spearville to Knoll with an additional segment from Knoll to Axtell, Nebraska. ITC Great Plains provided notice that it would undertake this project also. As a result, KETA is now in the position of monitoring the progress of ITC Great Plains on these two projects (see Figure 2). Separately, Westar has announced plans to construct a $345 \mathrm{kV}$ line from Wichita north to Salinas, Kansas, and a separate $345 \mathrm{kV}$ line also originating near Wichita and continuing south to Perry, Oklahoma. ${ }^{\mathrm{m}}$ Although KETA has effectively been supplanted in the transmission projects it wanted to sponsor, KETA officials indicate that the transmission activity in Kansas is an early indication of KETA's success by providing an impetus for transmission to precede without KETA's financial or direct involvement. Indeed, KETA officials have stated that KETA will be a success if companies build transmission without KETA being involved at all. ${ }^{\mathrm{n}}$

\footnotetext{
${ }^{j}$ Southwest Power Pool. (April 2007). Kansas Electric Transmission Authority (KETA) Study. http://sppoasis.spp.org/documents/swpp/transmission/ketanew.doc. (Accessed February 1, 2008).

${ }^{\mathrm{k}}$ Kansas Electric Transmission Authority. (July 2007). Framework for Considering a Notice to Proceed With Construction. http://www.accesskansas.org/keta/Notice.shtml. (Accessed February 12, 2008).

${ }^{1}$ Kansas Electric Transmission Authority. (August 2007). Letter from ITC Great Plains. http://www.accesskansas.org/keta/Notice.shtml. (Accessed February 12, 2008).

${ }^{\mathrm{m}}$ Westar Energy. Transmission Projects. http://www.westarenergy.com/corp_com/contentmgt.nsf/publishedpages/transmission. (Accessed February 12, 2008).

n Presentation of the Honorable Carl Holmes to the National Wind Coordinating Collaborative's Southwest Power Pool Workshop, Dallas, Texas, August 22, 2007.
} 
Figure 2. Proposed Kansas Transmission Projects

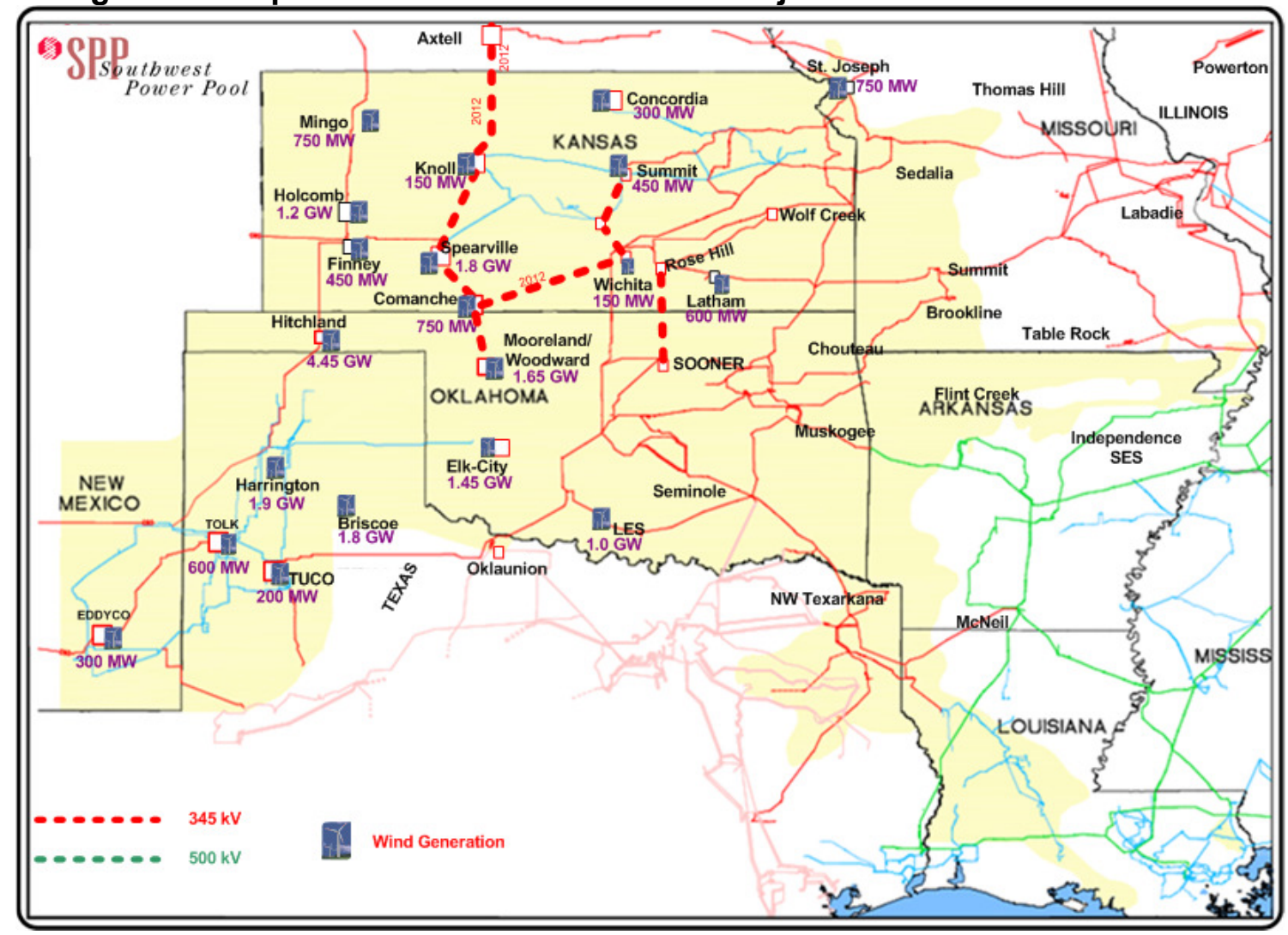

Source: Quantas Technology and Southwest Power Pool. (March 2008). Final Report on the Southwest Power Pool (SPP) Updated EHV Overlay Study.

http://www.spp.org/publications/Quanta_Technology_March_2_2008_Update_to_the_EHV_Study_ Final_Report.pdf. (Accessed March 26, 2008).

To date, WIA is the only state transmission infrastructure authority to have issued bonds. In September 2005, WIA did a private placement of bonds to the Wyoming State Treasurer, amounting to $\$ 34.5$ million. The proceeds financed three-quarters of the cost of the Hughes Transmission Project, a 130-mile, $230 \mathrm{kV}$ transmission line being constructed by the Basin Electric Power Cooperative of Bismarck, North Dakota. WIA estimates it will receive about $\$ 600,000$ in proceeds over 20 years through a loan fee structured into the agreement. ${ }^{\circ}$

WIA has several other transmission projects in various stages of development. In 2008, WIA plans to hold an open season to allocate transmission capacity from the planned WyomingColorado Intertie Transmission Project (see Figure 3). The Intertie Project was first identified as one a Rocky Mountain Area Transmission Study (RMATS) projects, a set of regional transmission projects aimed at enhancing the grid in Wyoming, Colorado, Idaho, and Montana. ${ }^{\mathrm{p}}$ WIA has partnered with Trans-Elect and the Western Area Power Administration (WAPA) to develop the Wyoming-Colorado Intertie section (TOT-3 under RMATS), aimed at building a

\footnotetext{
${ }^{\mathrm{o}}$ Wyoming-Colorado Intertie Transmission Project. http://www.wyia.org/wci/index.html. (Accessed February 12, 2008).

${ }^{\mathrm{p}}$ Rocky Mountain Area Transmission Study. (September 2004).

http://psc.state.wy.us/htdocs/subregional/FinalReport/rmatsfinalreport.htm. (Accessed January 30, 2008).
} 
345-kV transmission line from Wyoming to the Pawnee substation in Colorado. Ultimately, between 800 and $900 \mathrm{MW}$ could be transferred between Wyoming and Colorado and, depending on the response to the open season, the line could be double-circuited to allow more capacity. The tentative on-line date is 2013 .

\section{Figure 3. Wyoming-Colorado Intertie Transmission Project}

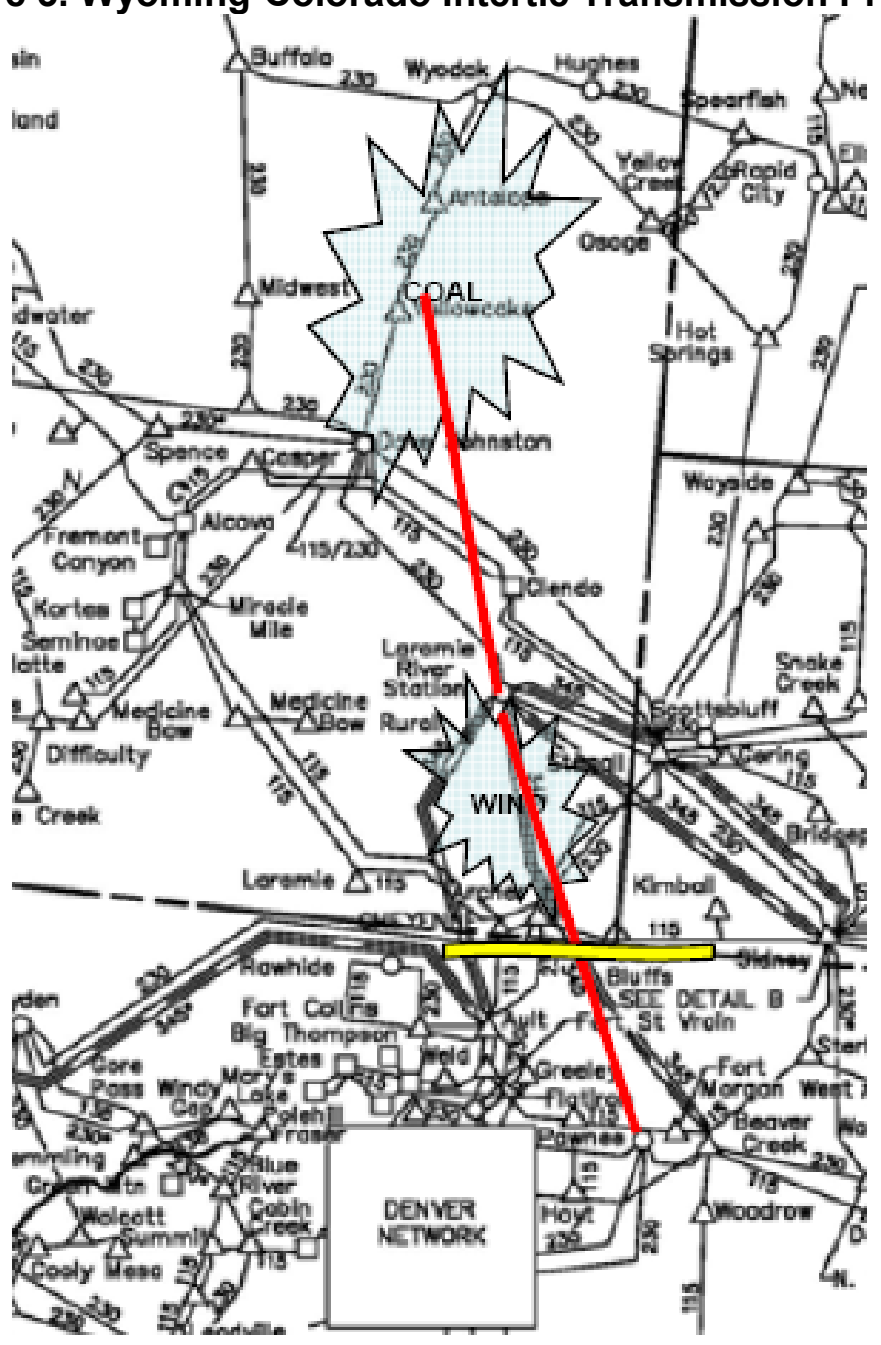

Source: Robert Mitchell. "TOT 3 Project Update: A Public/Private Partnership," Presented at the Wyoming Infrastructure Authority Board Meeting. http://www.wyia.org/wci/presentations/TOT3\%20Presentation--1-302007.pdf (Accessed March 14, 2008). 
WIA holds a $10 \%$ stake in a potentially much larger project, the TransWest Express/Gateway South project that could transmit between 4,500 and 7,500 MW of Wyoming coal and wind generation into the Desert Southwest (see Figure 4). WIA has partnered with Arizona Public Service (APS) and National Grid, and collectively the participants will initially invest about \$100 million to design and engineer the line and secure necessary permits and route right-of-ways. In August 2007, WIA entered into an interim agreement with APS, National Grid, and PacifiCorp to potentially co-develop the TransWest Express with Gateway South, a proposed transmission line by PacifiCorp that would extend from Wyoming into Utah and into the Desert Southwest. National Grid will be the lead developer for both lines, with active participation from WIA, APS, and PacifiCorp. Right-of-way applications have been filed, and the participants are working with the Bureau of Land Management on developing an environmental impact statement. $^{\mathrm{q}}$

Figure 4. TransWest Express/Gateway South Transmission Projects

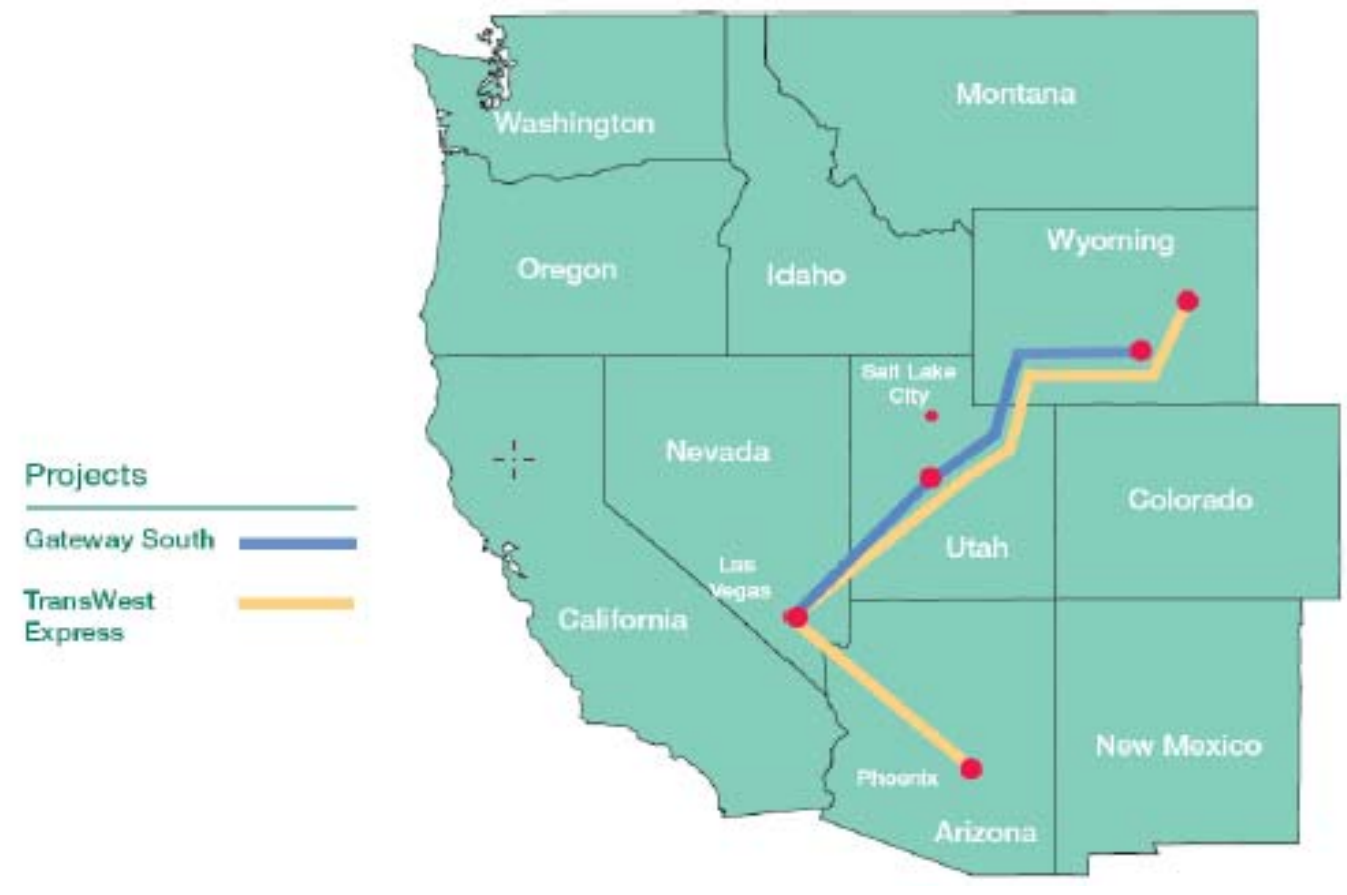

Source: Robert Stade. "TransWest Express and Gateway South." Presentation before the Roping the Wind Conference, Douglas, Wyoming. January 8, 2007. www.wyia.org. (accessed February 12, 2008).

WIA is also participating with CEDA, potentially RETA, and several utilities in studying the feasibility of the High Plains Express, a potential $500 \mathrm{kV}$ project from northeast Wyoming heading south through eastern Colorado to New Mexico and Arizona (See Figure 5). As now conceived, the High Plains Express could consist of two $500 \mathrm{kV}$ lines

\footnotetext{
q Stade, R. (January 2007). "TransWest Express and Gateway South." Presentated at the Roping the Wind Conference, Douglas, Wyoming. http://www.wyia.org. (Accessed February 12, 2008).
} 
spanning 1,200 miles carrying 2,000 to 3,000 MW. If developed, the High Plains Express project could tie in with the Wyoming-Colorado Intertie project; the proposed Eastern Plains Transmission Project in eastern Colorado; and the proposed New Mexico Wind Collector System and SunZia transmission projects.. Feasibility studies indicate that the project has significant benefits. Next steps include more detailed system, siting, and economic studies; determining who will participate in the project; more precisely defining the project; followed by design and engineering, siting, right of way procurement, and construction. Assuming these activities can be successfully accomplished, the High Plains Express project could begin operating by 2017 . $^{\mathrm{r}}$

\section{Figure 5. High Plains Express Transmission Project}

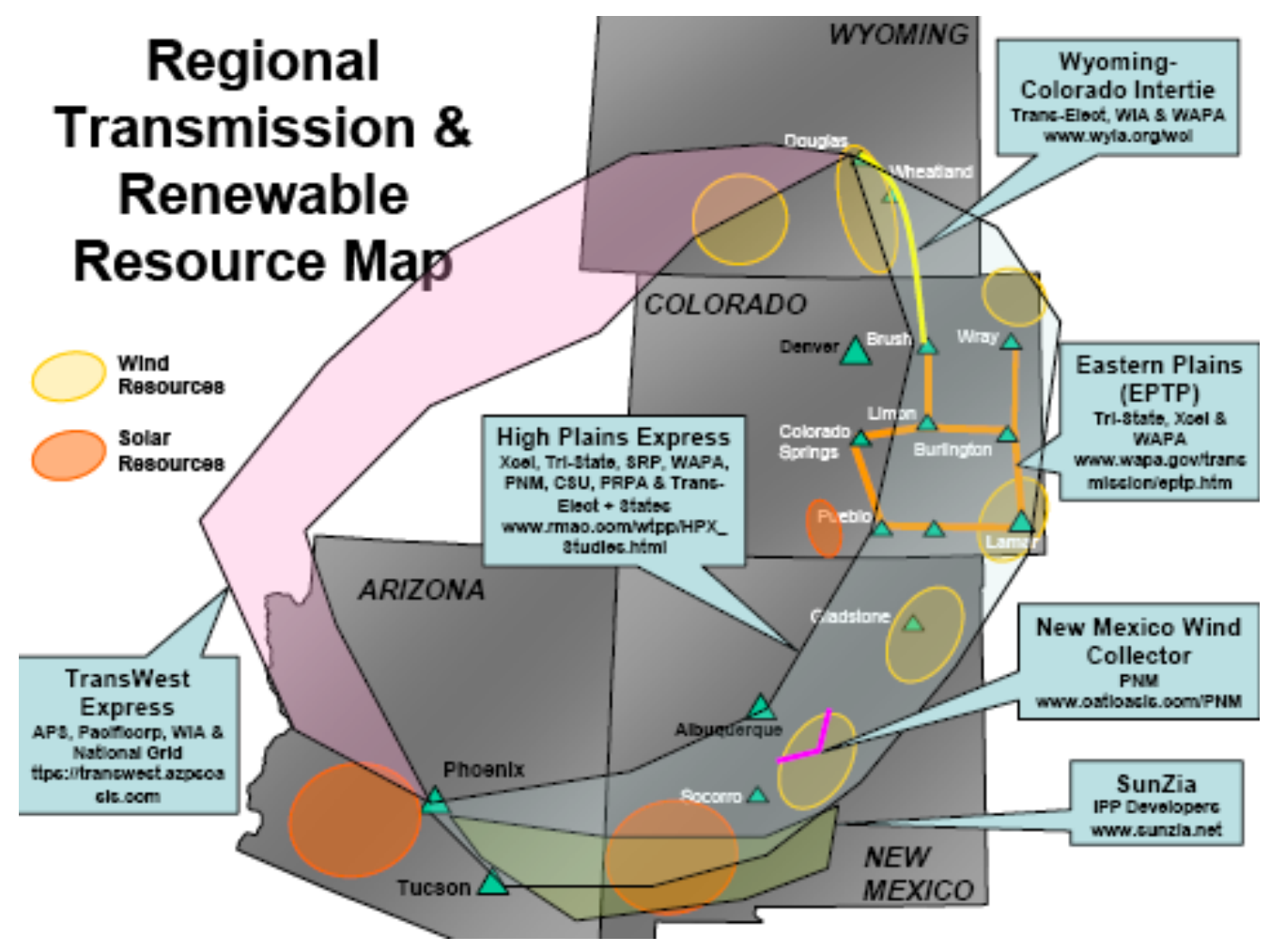

Source: Vaninetti, J. (December 2007). "Regional Transmission Development: High Plains Express Project." Presented at the Colorado Clean Energy Development Authority, Denver, Colorado. http://www.wyia.org. (Accessed February 12, 2008).

\footnotetext{
${ }^{\mathrm{r}}$ Vaninetti, J. (September 2007). "Enabling Renewables Via Transmission." Presentated at the Increasing Renewable Energy in the Western Grid Summit, Fort Collins, Colorado.

http://www.nationalwind.org/pdf/Vaninettiv2NWCCTrans-Elect.pdf. (Accessed February 12, 2008).
} 


\section{Implications for Wind Power}

All seven state transmission infrastructure authorities are located in states with highquality wind resources. As such, any success these authorities have in funding and/or supporting new transmission could lead to increased market opportunities to wind power. The total transfer capability of the Wyoming-Colorado Intertie and the TransWest Express/Gateway South projects, for example, amount to about 8,500 MW. Already, it is expected that wind power will make up most, if not all, of the capacity on the WyomingColorado Intertie, as well as some of the capacity on the High Plains Express project. In all, about 3,000 MW of wind power could be developed from these transmission projects, and that does not account for proposed transmission projects in Kansas, other large regional projects such as TransWest Express/Gateway South, or for the supporting transmission projects that could be part of High Plains Express that could result in more wind power (see Table 2). The actual amount of wind energy that is transmitted on these lines, should the transmission projects be developed, will depend on, among other factors, state energy and environmental policies and wind energy economics as compared to other energy resources.

\section{Table 2. Potential Large Transmission Projects that State Transmission} Infrastructure Authorities May be Involved In

\begin{tabular}{|l|c|c|c|}
\hline Name & $\begin{array}{c}\text { Likely Fuel Types } \\
\text { on Line }\end{array}$ & $\begin{array}{c}\text { Total Transfer } \\
\text { Capability (MW) }\end{array}$ & $\begin{array}{c}\text { Potential MW } \\
\text { of Wind** }\end{array}$ \\
\hline $\begin{array}{l}\text { Wyoming-Colorado } \\
\text { Intertie }\end{array}$ & $800-900$ & $800-900^{*}$ \\
\hline $\begin{array}{l}\text { TransWest } \\
\text { Express/Gateway South }\end{array}$ & $\begin{array}{c}\text { Wind, Coal, Natural } \\
\text { Gas }\end{array}$ & $4,500-7,500$ & Unknown \\
\hline High Plains Express & $\begin{array}{c}\text { Wind, Solar, Coal, } \\
\text { Natural Gas }\end{array}$ & 3,000 & $1,000-2,000$ \\
\hline Eastern Plains & $\begin{array}{c}\text { Coal, Natural Gas } \\
\text { Coal, Wind }\end{array}$ & $1,200-1,800$ & 0 \\
\hline X-Plan & $\begin{array}{c}\text { Natural Gas, Wind, } \\
\text { Solar, Geothermal }\end{array}$ & 3,000 & Unknown \\
\hline SunZia & Unknown \\
\hline
\end{tabular}

${ }^{*}$ Actual amount will depend on the results of an open season to be held in Summer 2008.

${ }^{* *}$ Based on respective project feasibility study results.

The other state transmission infrastructure authorities have not been as active as Wyoming and Kansas. NDTA brokered a deal between the Bank of North Dakota and Basin Electric Power Cooperative for \$25 million to fund a new transmission line in southwest North Dakota. IERA is considering its first transmission financing, a 
$\$ 6.5$ million bond for an Idaho electric cooperative. SDEIA has funded several resource potential and transmission evaluation studies. RETA and CEDA are getting their organizations up and running but as noted, they are both engaged with WIA on the High Plains Express project.

\section{Issues Facing State Infrastructure Authorities}

To date, state transmission infrastructure authorities have assumed various elements of two roles: 1.) a promoter of facilities and transmission projects, and 2.) a participant in the planning, development, and financing of transmission projects. State transmission infrastructure authorities have also served as early-stage transmission incubators by preparing state maps of potential energy resources, identifying transmissions projects to access those resources, and shepherding transmission projects through the early developmental stages. State transmission infrastructure authorities also have powers with respect to siting that other industry entities may lack. They can establish transmission corridors; adopt, amend, or repeal bylaws; and most have been granted the power of eminent domain within their respective states for project siting purposes.

Transmission planning and development is a complex process involving many pieces and players. The individuals charged with the oversight of state transmission infrastructure authorities have found it challenging to fully understand all the issues involved, requiring some to learn about transmission projects and ensure that the members of the board of directors have a clear picture of what is required. Some state transmission infrastructure authorities have hired outside experts to help map the energy resource potential in their respective states, examine transmission system constraints, and offer recommendations on improvements. SDEIA, for example, has conducted several studies on the transmission grid in South Dakota and options for developing coal, wind, and nuclear plants, and exporting the power to other states. KETA spent most of its first year learning about transmission planning and development issues.

Clearly identifying where the energy resources are and where the electric demand is needed is very important at the outset. Following this, specific projects need to be identified, and feasibility and engineering studies conducted. This process has proved to be time consuming and costly, taking twice as long and costing twice as much as expected. ${ }^{\mathrm{s}}$ Some authorities have focused on creating public-private partnerships to help fund these efforts.

Funding has been a limiting factor for some state transmission infrastructure authorities. WIA has been well funded, with a $\$ 1.6$ million operating budget for 2007 and 2008, giving it the ability to support three full-time staff members, and a $\$ 10$ million

\footnotetext{
${ }^{\mathrm{s}}$ National Wind Coordinating Collaborative. (October 2007). Thirteenth NWCC Transmission Update. http://www.nationalwind.org/pdf/NWCCtransmissionupdateOct07FINAL.pdf. (Accessed February 12, 2008).
} 
contingency fund for project development. ${ }^{t}$ KETA has also been well supported, with operational funds totaling \$170,000 for 2007 and 2008, and a $\$ 1$ million contingency fund. ${ }^{u}$ RETA received $\$ 1$ million in start-up funding for 2007 and 2008. ${ }^{\mathrm{v}}$ SDEIA has received a total of $\$ 303,000$ in funding and NDTA is part of the North Dakota Industrial Commission and therefore works under its budget. IERA and CEDA have had the most difficulty with respect to funding. IERA did not receive any funding from the legislature, but did obtain \$50,000 from the Idaho Consumer-Owned Utilities Association to assist with start up operations. ${ }^{\mathrm{w}}$ The state of Colorado has a constitutional provision that caps growth in government spending at the level of inflation, largely preventing the legislature from providing any funding to CEDA. Some funding is being provided to CEDA by the Colorado Clean Energy Fund, which is part of the existing Governor's Energy Office that facilitates clean energy development in the state.

These funding issues have limited some of the state transmission infrastructure authorities' abilities to hire staff, conduct feasibility studies, sponsor larger but more risky transmission projects, and participate in regional transmission planning initiatives. State transmission infrastructure authorities with little or no funding have focused on short-term transmission projects that can be put in place quickly and generate some revenue. IERA, for example, will soon close on a $\$ 6.5$ million project to construct a transmission line for a rural electric cooperative. While this may generate immediate results, not having operational funding makes it initially difficult for a state infrastructure authority to participate in a larger transmission project to fund feasibility studies, or to take part in regional transmission planning initiatives.

These funding and bonding differences have resulted in state transmission infrastructure authorities choosing to focus their efforts in different ways. WIA has formed partnerships with electric utilities and transmission developers to explore development of large, multi-state transmission projects. KETA has taken on the role of project catalyst, pushing projects forward and then bowing out when private entities express interest and assume control of the projects. SDEIA has focused on identifying and cataloguing development opportunities in South Dakota. NDTA prefers to act as a facilitator, brokering deals between developers and financers. RETA and CDEA are engaged in getting their organizations up and running and ensuring their board members are informed.

One issue that unites the state transmission infrastructure authorities is their desire to have the bonds they issue exempt from federal taxes. If achieved, such an exemption

\footnotetext{
${ }^{\mathrm{t}}$ Wyoming Infrastructure Authority. State of Wyoming 2007-2008 Biennium Budget Request. http://www.wyia.org/Pubs/WIA_Budget.htm. (Accessed February 12, 2008).

${ }^{\mathrm{u}}$ Kansas Electric Transmission Authority. (January 2008). 2007 Annual Report to the Governor and the Legislature. http://www.accesskansas.org/keta/resources.shtml. (Accessed February 4, 2008).

${ }^{v}$ New Mexico Renewable Energy Transmission Authority. Fact Sheet on The Renewable Energy Transmission Authority. http://www.emnrd.state.nm.us/main/documents/HB-188-RETA-fact-sheet-07.pdf. (Accessed February 12, 2008).

${ }^{\mathrm{w}}$ Idaho Energy Resources Authority. (October 2005). Minutes of the Idaho Energy Resources Authority Directors' Meeting, Boise, Idaho.. http://www.iera.info/pdf/minutes_10_26_05.pdf. (Accessed February 12, 2008).
} 
would allow state transmission infrastructure authorities to offer bonds at a $1.5 \%$ to $2 \%$ lower interest rate. WIA has financially supported federal lobbying efforts for such a federal tax exemption, but unsuccessfully to date.

\section{Conclusion and Recommendations}

Although investments in transmission are increasing, transmission investment has lagged behind growth in electric demand for many years. Several well-known and welldiscussed obstacles affect transmission development, from high capital investment requirements; uncertain cost allocation among multiple parties; and siting and permitting challenges. State transmission infrastructure authorities are potentially a new tool for helping to develop transmission. These authorities are authorized to issue revenue bonds to support investments in, and sometimes ownership in, transmission projects, and in some cases, generation, distribution, manufacturing, and transportation projects. State transmission infrastructure authorities have brought a focus to transmission that has been either absent or has not been sustained over time. This result may not have been anticipated when state transmission infrastructure authorities were formed, but has come about through regular public meetings of the board of directors and other public outreach events.

Since all of the state transmission infrastructure authorities are less than five years old, and transmission development can take years, it is perhaps not surprising that they are still evolving. So far, only one state-Wyoming - has issued bonds for a transmission line. However, Kansas and North Dakota have also had success in encouraging new transmission without issuing bonds. In the case of Kansas, KETA, who can own (but not operate) transmission appears to have used that potential threat as a means of cajoling private entities to sponsor at least two new transmission projects, the first to be built in the state in decades. Wyoming will sponsor an open season for the Wyoming-Colorado transmission line in 2008 amidst indications that wind may take up most, if not all, of the capacity on the line.

Yet to be determined is whether state transmission infrastructure authorities can help stimulate large, multi-state regional transmission projects. Wyoming has entered into joint development agreements for two such projects, the High Plains Express and the TransWest Express projects. Although just established in 2007, the Colorado and (potentially) the New Mexico authorities plan to participate in High Plains Express, and at least in the case of New Mexico, that state's authority has desires to build transmission to export renewable resources from New Mexico to surrounding states.

Should states contemplate creating a transmission infrastructure authority, they may wish to consider the following:

- Funding. Although other factors undoubtedly come into play, it is perhaps no accident that two of the more active state transmission infrastructure authorities (Kansas and Wyoming) are among the better-funded. 
Adequate funding for both operating costs and for contingencies allows state transmission infrastructure authorities to hire sufficient staff, invest in early-stage feasibility studies and plans, and build support for largescale transmission projects. Other states, notably Idaho, have been successful with minimal funding and relying on consultants acting on a "success fee" basis. Making that approach work places more emphasis on the short-term and more immediate transmission projects to generate cash flow, and does not necessarily allow participation in regional planning initiatives or in large-scale, multi-state transmission projects that may take several years to develop, if they are developed at all.

- Independence. Two state transmission infrastructure authoritiesColorado and South Dakota - require legislative approval before they can issue bonds. While legislative oversight is clearly necessary, requiring legislative approval for state transmission infrastructure authority bonds may introduce uncertainty into the planning and financing of these bonds and ultimately slow or even stymie the transmission projects that are to be supported. To the extent feasible, states contemplating the establishment of state transmission infrastructure authorities may wish to consider traditional legislative oversight rather than requiring approval of each proposed state transmission infrastructure authority bond.

- Start Small but Think Big. Planning and developing large-scale transmission projects is complex and involves multiple marketparticipants working on complicated technical and economic issues. Planning and putting in place a small transmission project initially allows state transmission infrastructure authorities to test the market for issuing revenue bonds and to become familiar with market participants in their state and region. But since a major driver for creating most state transmission infrastructure authorities is to create economic development by exporting energy (primarily coal and wind) to load centers that may be several hundred miles away, state transmission infrastructure authorities should also pursue large-scale, multi-state transmission projects.

- Consider Financial Partnership with Other Entities. WIA has established partnerships with National Grid, Trans-Elect, and several electric utilities to leverage both financial clout and technical expertise in pursuing largescale, multi-state transmission projects. Such partnerships help minimize the financial strain of large-scale transmission projects and also have the benefit of building market participant support for large-scale transmission projects as well.

- Consider Allowing Ownership of Transmission Facilities. Some state laws creating transmission infrastructure authorities require the authorities to divest transmission assets as soon as economically practicable. WIA, KETA, RETA, and IERA are allowed to own (with conditions) 
transmission facilities over the long term, and although other factors are certainly involved, the implicit threat of competition for transmission facilities appears to have helped stimulate several new transmission projects in Kansas. Allowing other entities to assume project development within a defined time period after a state transmission infrastructure authority announces interest in developing a transmission project may help mitigate concerns about unfair competition or market interference by government entities. 


\section{COLORADO}

\section{Legislation}

Name: $\quad$ Colorado Clean Energy Development Authority

Legislation: House Bill 07-1150

http://www.leg.state.co.us/Clics/Clics2007A/csl.nsf/MainBills?openFrameset

Date Enacted: May 2007

Governed by: Independent State Instrumentality

Administered: Nine-member Board

Reports to: Governor; Agriculture, Natural Resources and Energy Committee of the

Financing Cap: None

Phone: $\quad 303-866-2100$

Fax: $\quad 303-866-2930$

Web site: $\quad$ http://www.colorado.gov/energy/utilities/clean-energy-developmentauthority.asp

Contact: $\quad$ Tom Plant, tom.plant@state.co.us

Morey Wolfson, morey.wolfson@state.co.us

303-866-2401

\section{Summary}

The Colorado Clean Energy Development Authority (CEDA) is a stand-alone entity created for the purpose of facilitating the production and consumption of clean energy. CEDA may finance projects located within or outside the state for the production, transportation, transmission, equipment manufacturing, and storage of clean energy, including pipelines, and related supporting infrastructure. CEDA provides project financing and development support but cannot own facilities. Clean energy is defined as: biodiesel; biomass; landfill gas; ethanol; non-fossilfueled fuel cells; zero-emissions generation technology; renewables including (but not limited to) solar, wind, and geothermal; and certain clean coal demonstration technologies. CEDA may also support non-clean energy transportation and storage projects as long as the project is expected to produce or utilize primarily clean energy within five years of becoming operational, or for a transmission project, the primary purpose is to transmit clean energy.

CEDA is governed by a nine-member board and is authorized to maintain offices and hire an Executive Director and other staff as it deems necessary. CEDA can also:

- Adopt, amend, or repeal bylaws

- Finance and refinance projects

- Issue revenue bonds pursuant to its own resolutions, though each issuance must first be approved by the legislature and some issuances may require a public vote

- Enter contracts and agreements; make loans; receive aid, grants, and contributions; and borrow funds to establish itself. 
The bonds issued and managed by CEDA are not obligations of the state and all CEDA facilities and revenues are exempt from state and local taxes.

House Bill 07-1150 directs CEDA to convene an advisory panel that will make recommendations on whether hydroelectric power should be included under clean energy; whether and what restrictions should be adopted for biomass; and whether integrated gasification combined cycle generation facilities or other clean coal technologies with carbon sequestration should be considered clean energy projects. CEDA is to convene the panel when sufficient funding has been received from gifts, grants, donations, or project fees. CEDA is required to submit an annual report to the Governor and various committees of the General Assembly outlining activities and expenditures by February $1^{\text {st }}$ of each year, and to prepare a three-year plan every three years beginning in February 2008.

\section{Organization Size and Structure}

CEDA is a stand-alone entity governed by a nine-member board of directors. Four of these members are ex officio: State Treasurer, Director of the Colorado Office of Economic Development, Commissioner of Agriculture, and Director of the Governor's Energy Office who will also serve as the Chairperson. Five board members are appointees serving staggered fouryear terms. One board member will be appointed by each of the following: Governor, Speaker of the House of Representatives, President of the Senate, Minority Leader of the House of Representatives, and Minority Leader of the Senate. The board members will elect from among them a vice-chairperson and a secretary. CEDA plans to hire an Executive Director in 2008. The appointees were announced in September 2007 and are as follows:

- Tom Plant, Chairman, Governor's Energy Office

- Cary Kennedy, State Treasurer

- John Stulp, Agriculture Commissioner

- Don Elliman, Director of the Office of Economic Development

- Lola Spradley, Former House Speaker

- Lee White, George K. Baum \& Co.

- Sam Weaver, Cool Energy

- Jeff Nathanson, National Jewish Hospital

- Joel Bladow, Tri-State Generation and Transmission

\section{Eligible Technologies and Applications}

CEDA can finance projects involved in the production and transport of all clean energy, which includes all renewable resources and all zero-emission technologies. CEDA can explore clean coal technology demonstration projects that include carbon capture and sequestration. The definition of transport includes electric transmission, pipelines, containers, rails, and trucks. CEDA may also support biomass resources projects that use energy that is not clean in the production, transportation, or storage of clean energy so long as the project is designed and expected to produce only clean energy within five years of becoming operational. Transmission projects may also transmit non-clean energy as long as the principle purpose of the project is to 
provide for transmission of clean energy. Similarly, storage and transportation projects may be used for non-clean energy as long as the project is designed and is expected to be used primarily for clean energy within five years of becoming operational.

\section{Financing}

CEDA may request and receive loans from the state government for funding the start-up of its facilities and operations. CEDA is receiving some start-up funding from the Colorado Clean Energy Fund. A separate fund for CEDA was created within the Treasury by House Bill 07-1150, however, CEDA is not a governmental entity, and therefore could not spend money from the fund. Clean-up legislation was introduced in the 2008 legislative solution to remedy this problem. CEDA can issue revenue bonds, though they must first be approved by the legislature, and will pay for those bonds out of revenues it derives from its projects. Voter approval of CEDA bonds is necessary if CEDA is not able to realize sufficient revenues to cover the bond payments due unless the bond payments are secured by a third-party financing agreement or reserve fund, or by a mortgage on the facilities.

The CEDA bonds are not liabilities of the state and there are, currently, no financial limits on the amount of bonds the CEDA may issue. However, scheduled bond repayments cannot exceed $\$ 8$ million in any single fiscal year. CEDA may plan and pursue projects at its own discretion, has not been directed to issue RFPs, and is not required to advertise intent to pursue a project. CEDA must, however, submit to the General Assembly by January $15^{\text {th }}$ each year a list of the proposed projects for which it is seeking legislative approval prior to entering into a financing agreement. House Bill 07-1150 granted pre-authorized financing in each year for the following: \$40 million in bonds for wind projects and $\$ 25$ million in bonds for solar projects. For all other projects, the Authority must gain approval from the Assembly prior to issuing the bonds.

CEDA cannot finance or refinance any transmission or clean energy project that is subject to regulation by the Colorado Public Utilities Commission without approval from the Commission. For projects with debt reserve requirements, CEDA must obtain a performance bond to guarantee completion of the project. Should debt reserve requirements fall below minimally required levels, the Governor can request legislative funding on behalf of CEDA.

\section{Activities to Date}

CEDA has joined the High Plains Express transmission project, which is developing a highvoltage system from northeast Wyoming heading south through eastern Colorado to New Mexico and Arizona. In addition to CEDA, Trans-Elect, the Western Area Power Administration, Salt River Project, Public Service Company of New Mexico, Xcel Energy, Colorado Springs Utilities, Platte River Power Authority, Tri-State Generation and Transmission Association, and the Wyoming Infrastructure Authority are also involved. The New Mexico Renewable Energy Transmission Authority is also considering participating in the project. Phase I consists of preliminary engineering and economic studies, and was completed in early 2008 showing positive benefits arising from the project. As a result, the project has moved to Phase II, the development stage, consisting of defining the project, ownership negotiations, studies on siting and economics, review of commercial issues, and addressing regulatory and 
policy issues. The project consists of two $500 \mathrm{kV}$ lines with 3,500 MW of capacity connecting four other transmission projects already under development into an integrated grid. These other projects are the Wyoming-Colorado Intertie, Eastern Plains Transmission Project, SunZia, and a New Mexico wind collector project. The project is expected to cost $\$ 5.13$ billion. 


\section{IDAHO}

\section{Legislation}

$\begin{array}{ll}\text { Name: } & \text { Idaho Energy Resources Authority } \\ \text { Legislation: } & \text { House Bill 106 } \\ & \text { http://www3.state.id.us/oasis/2005/H0106.html } \\ \text { Amendments: } & \begin{array}{l}\text { Senate Bill 1192 } \\ \text { http://www3.state.id.us/oasis/2005/S1192.html }\end{array} \\ & \text { House Bill 32 } \\ & \text { http://www3.state.id.us/oasis/H0032.html\#engr } \\ & \text { March 2005 } \\ \text { Date Enacted: } & \text { April 2005 } \\ \text { Date Amended: } & \text { March 2007 } \\ & \text { Independent Public Corporation } \\ \text { Governed by: } & \text { Seven-member Board } \\ \text { Administered: } & \text { Idaho Legislature and Governor } \\ \text { Reports to: } & \text { None } \\ \text { Financing Cap: } & \text { 208-344-3873 } \\ \text { Phone: } & \text { 208-344-0077 } \\ \text { Fax: } & \text { http://www.iera.info/index.html } \\ \text { Web site: } & \text { Ron Williams, ron@williamsbradbury.com } \\ \text { Contact: } & \text { 208-344-6633 }\end{array}$

\section{Summary}

The Idaho Energy Resources Authority (IERA) was created in 2005 for the purpose of promoting the development and financing of electric generation and transmission facilities in Idaho for the benefit of Idaho utilities and consumers. About 50\%of the electricity consumed in Idaho is imported, and the Idaho Legislature believed that infrastructure investment is necessary to provide adequate reserves, maintain reliability, and reduce market volatility. IERA is focused on providing electricity at cost-based rates through promoting the development and financing of generation and transmission facilities for participating utilities. Participating utilities are defined as any public or private corporation, cooperative, municipal corporation, political subdivision, government agency, or joint operating entity that:

- Owns and operates an electric utility system with customers in a service area within Idaho

- Provides electric generation, power supply, transmission, or ancillary related services to a participating utility

- Is organized or operates as a regional transmission organization that includes all or part of Idaho and one or more states.

The IERA is an independent public corporation governed by a seven-member board of directors serving five-year terms. The IERA can help plan, finance, construct, develop, 
acquire, maintain, and operate electric generation, distribution, and transmission facilities, and any supporting infrastructure. IERA cannot develop or finance a facility unless it has a contractual arrangement with a participating utility. Once the facility is completed, it must be managed by a participating utility or another party under contract. IERA was given the authority to:

- Adopt relevant bylaws

- Maintain offices and staff, and employ consultants, attorneys, or other professionals

- Execute contracts and sue or be sued

- Acquire, own, lease, and dispose of real or personal property in connection with generation and transmission facilities

- Acquire, construct, renovate, maintain, operate, and lease generation, distribution, and transmission facilities

- Enter into contracts for fuel supplies and sell or lease output from generation, distribution, and transmission facilities to one or more participating utilities

- Borrow money and issue revenue bonds

- Make loans to participating utilities to finance the cost of transmission, distribution, and generation facilities

- Establish rules and regulations for the use of generation, distribution, and transmission facilities, and to designate a participating utility as IERA's agent

- To assign and pledge all or part of IERA's revenues and income, or mortgage any or all of IERA's generation, distribution and transmission facilities for bondholders to enable bond financing

- Participate in cooperative ventures with any agencies or organizations

- Establish and collect rents and fees from its facilities to pay for the facility and bond costs.

IERA is permitted to use revenues from its bonds to pay for its operating expenses. Facilities owned by IERA are exempt from state taxes. IERA also must submit an annual report to the Governor and the Legislature.

IERA has eminent domain authority for securing real or personal property, although it is limited for generation and transmission facilities and cannot use eminent domain for obtaining utility assets. IERA is also prohibited from providing financing for acquiring utility assets by or via the threat of eminent domain and from providing electricity at retail to Idaho customers.

The statute encourages IERA to involve multiple utilities on a joint and cooperative basis, and IERA is required to offer all utilities a chance to participate in developing or purchasing the output of a generation, distribution, and transmission facility. IERA cannot proceed with a project unless it has a contract with at least one utility or, in the case of a renewable generation facility, a utility or an independent power producer. Upon final payment of the bonds, IERA is required to convey ownership of the generation, distribution, or transmission facility to the participating utility or utilities, unless these utilities request IERA to keep ownership of the facility on their behalf. 
A month after the initial legislation passed, the Idaho Legislature amended the statute to allow independent power producers to seek bond funding from IERA for renewable energy generation projects. In 2007, IERA's authority was further expanded to include development and funding for electric distribution systems, along with generation and transmission. It also grants IERA the ability to manage and operate its own facilities, and grants permission to the State Treasurer to invest in IERA bonds.

\section{Organization Size and Structure}

A seven-member board appointed by the governor to five-year terms governs the IERA. Directors can serve no more than two consecutive terms. The board members are listed below.

- E. Robert Mooney, Malacha Hydro, Chairman

- N. Charles Hedemark, formerly of Intermountain Gas Company

- Darrell Wayne Kerby, City of Bonners Ferry and Pace-Kerby \& Co., Inc.

- John V. Evans, Sr., Former Governor of Idaho

- Ralph Williams, United Electric Cooperative, Inc.

- Larry A. Crowley, The Energy Strategies Institute

- Randolph J. Hill, Washington Group International

\section{Eligible Technologies and Applications}

IERA may be involved with all aspects of energy projects including generation, transmission, distribution, and fuel supply management. This gives the IERA a large amount of discretion in selecting projects to finance. The IERA act includes a provision allowing IERA to finance renewable energy projects for the benefit of independent power producers as well as participating utilities. Technologies defined as renewable energy include biomass, fuel cells, geothermal energy, waste heat, cogeneration, solar energy, waterpower, and wind. Nonrenewable energy projects can only be financed for the benefit of participating utilities.

\section{Funding and Financing}

The IERA has the authority to issue revenue bonds, make secured and unsecured loans, and borrow money to finance projects. Bonds are issued through resolutions of the board and are obligations of the IERA and not the state of Idaho. Bonds issued by the IERA are exempt from Idaho income taxes. No financing cap has been set. IERA can also purchase or refinance outstanding bonds as they see necessary.

The IERA does not receive any funding from the state of Idaho and does not yet have fulltime staff. IERA is expected to finance its own operations through the revenue received from its bonds. In 2006, the IERA received \$50,000 from the Idaho Consumer-Owned Utilities Association for operational funding. IERA will not have full-time staff until financing or loan transactions generate enough income for IERA to have staff. In the interim, IERA is relying on part-time staff and other professionals such as lawyers, lenders, and financial advisors on a deferred or success-fee basis. In the near term, this 
will mean focusing on projects with a high probability of success and low risk in order to make the best use of the consultants and other professionals, and to generate revenue to support IERA's operations. The IERA recently hired Lehman Brothers to act as an investment banker.

Subject to approval by the Idaho Public Utilities Commission, a utility that is part of an IERA generation or transmission project may establish one or more rate stabilization, cost recovery, or power cost adjustment charges in regards to a generation, distribution, or transmission facility sponsored by the IERA. A utility not subject to jurisdiction by the Idaho Public Utilities Commission may also establish such charges provided notice of at least 15 days is given and a public hearing is held.

\section{Activities to Date}

IERA submitted its first annual report in March 2007. The report outlines IERA's key goals developed in a statement of purpose as follows:

- Seek high-quality utility-related generation and transmission projects that the IERA deems to be of high-value and low-risk

- Build a successful loan portfolio and issue bonds to finance new transmission lines and facilities or to expand existing facilities required to support new generation or greater transfers from other regions

- Own transmission facilities in those instances where private investment is not offered or available, or is not the lowest cost alternative

- Enter into partnerships with public or private entities to finance the construction or upgrading of transmission facilities.

The IERA did not fund any projects in 2006 and has no bonds outstanding as of December 2006. However, IERA's annual report lists a number of projects as being under consideration. These include:

- Bogus Basin Transmission Line. Refinancing, at a cost of \$2.5 million, of the 69 $\mathrm{kV}$ transmission line from Idaho Power's substation at Hidden Springs to serve Bogus Basin Ski Area and broadcasters at Deer Point above Boise

- Raft River Duck Valley Transmission Line. Permanent financing of the $138 \mathrm{kV}$ transmission line from the C J Strike substation of Idaho Power to the Duck Valley Indian Reservation served by Raft River Electric

- Caribou Transmission Line. Financing of a tap of the $115 \mathrm{kV}$ Rocky Mountain Power (PacifiCorp) Bridger Transmission Line near Soda Springs, Idaho, to the Lower Valley Energy (LVL) substation in Afton, Wyoming. The estimated cost is $\$ 15$ million. Financing of the LVL transmission and substation facilities is only contemplated at this time, but possible inclusion of the Rocky Mountain Power facilities is possible and would triple the scope of the financing. 
- Intermountain Power Project. IERA plans to contribute about $\$ 150$ million in construction financing to help municipal and cooperative utilities buy partownership of the proposed 900 MW Intermountain Power Project Unit \#3, a 900 MW coal plant being developed in Utah. Various utilities participating in the project have threatened to sue the Los Angeles Department of Water and Power and the Intermountain Power Agency for withdrawing from the project, although the parties are in the midst of discussions. Assuming the parties can reach a resolution, construction may begin in 2008 and the plant could come online in 2012.

- Idaho Falls Municipal Loop. This consists of a $161 \mathrm{kV}$ transmission loop to extend a transmission ring around Idaho Falls, Idaho, at an estimated cost of $\$ 10$ million. Several other municipalities and cooperatives are interested in a joint bond issuance for distribution financing. 


\section{KANSAS}

\section{Legislation}

$\begin{array}{ll}\text { Name: } & \text { Kansas Electric Transmission Authority } \\ \text { Legislation: } & \text { Kansas House Bill } 2263 \\ & \text { http://www.kslegislature.org/bills/2006/2263.pdf } \\ \text { Amendment: } & \text { Kansas House Bill 2306 } \\ & \text { http://www.accesskansas.org/keta/Legislation/2007_2306.pdf } \\ \text { Statutes Codified: } & \text { K.S.A 74-99d01, et. seq. } \\ & \text { http://www.accesskansas.org/keta/Legislation/Statutes.pdf } \\ \text { Date Enacted: } & \text { March 2005 } \\ \text { Date Amended: } & \text { April 2007 } \\ \text { Governed by: } & \text { Independent Public Corporation } \\ \text { Administered: } & \text { Seven-member board } \\ \text { Reports to: } & \text { Kansas Legislature and Governor } \\ \text { Financing Cap: } & \text { None } \\ \text { Phone: } & \text { 785-296-4408 } \\ \text { Web site: } & \text { http://www.accesskansas.org/keta/ } \\ \text { Contact: } & \text { keta@ink.org } \\ & \text { Rep. Carl D. Holmes, repcarl@aol.com } \\ & \text { 620-624-7361 }\end{array}$

\section{Summary}

The stated purpose of creating the Kansas Electric Transmission Authority (KETA) is "to further ensure reliable operation of the integrated electrical transmission system, diversify and expand the Kansas economy and facilitate the consumption of Kansas energy through improvements in the state's electric transmission infrastructure." KETA is an independent entity administered by a seven-member board of directors. KETA is authorized to adopt bylaws, employ staff, make and execute contracts, borrow funds, and own property. KETA can also incur or assume debt and enter into contracts with the Kansas Development Finance Authority to provide for project financing. State and local governments can also lease, lend, grant, or convey property to KETA without public notice.

KETA can recover costs through tariffs of the Southwest Power Pool (SPP) regional transmission organization and participate in and coordinate with the planning activities of SPP and adjoining regional transmission organizations. KETA can plan for, finance, construct and own transmission facilities, and participate in joint ventures but cannot operate or maintain facilities. The Board is required to operate and maintain its transmission lines via contract with utilities. KETA also has the right to exercise the power of eminent domain, if necessary, for constructing, upgrading, or repairing electric transmission facilities. KETA and its facilities are exempt from state taxes, except property taxes. 


\section{Organization Size and Structure}

KETA is governed by a seven-member board of directors serving staggered, four-year terms. The Governor appoints three of the board members, subject to State Senate confirmation. The other four members are state legislators acting on an ex officio basis and consist of the two Chairs and the two ranking minority party members of the House and Senate Utilities Committees. The current board members as of July 2007 are:

- Representative Carl Holmes, Chair

- Earnie Lehman, Midwest Energy, Vice-Chair

- Tim McKee, Triplett Woolf \& Garretson LLC, Secretary

- Senator Jay Emler

- Les Evans, Kansas Electric Power Cooperative, Inc.

- Representative Annie Kuether

- Senator Janis Lee

The chairperson, vice-chairperson, and secretary are elected annually.

\section{Eligible Technologies and Applications}

The scope of KETA's authority is defined by legislation as being applicable only to electric transmission facilities or related supporting infrastructure. There are no restrictions in the legislation as to what types of resources or technology KETA may pursue to build electric transmission lines.

\section{Funding and Financing}

During state fiscal years 2007 and 2008, KETA's operations are financed from the Public Service Regulation Fund pursuant to legislative appropriation. KETA has been provided with part-time staff by the Kansas Legislative Research Department and the Kansas Corporation Commission (KCC). KETA's authorized expenditure limitation for FY 2007 was \$70,000. For FY 2008 the legislatively established expenditure limitation for KETA was $\$ 100,000$. KETA has also received authorization to expend up to $\$ 1$ million from a special fund established by the Legislature for planning related to transmission projects.

KETA is authorized to borrow funds and to contract with the Kansas Development Finance Authority, which can borrow money, issue revenue bonds, and provide financing for KETA projects. KETA may recover project costs, including amounts necessary to repay loans and bonds, through tariffs of SPP and additionally through assessments levied by the KCC against all electric utilities, municipal utilities, and rural electric cooperatives in Kansas. KETA is exempt from state income and sales taxes, and pays the same property tax rate as privately-owned and cooperatively-owned utilities.

KETA is authorized to plan and develop infrastructure projects but must work with SPP and can only sponsor facilities which SPP has determined are compatible with SPP's transmission plan. If KETA is considering a project it must first advertise its intentions, giving other entities 90 days to provide the Board with notification of intent to finance and 
construct the project. KETA may continue with the project if no private entity comes forward. Any entity that has expressed intent to undertake the project identified by KETA then has 180 days to commence performance of the project. If the private entity does not commence performance, KETA may proceed with the project. KETA is not required to divest itself of projects it has developed and may continue to own the facilities. If financing can be acquired, KETA also has the ability to build transmission projects that are not currently economic but may be economic over the long term or may be necessary to ensure future reliability. If projects do not recover revenue requirements through SPP tariffs, revenue shortfalls can be allocated amongst ratepayers in all of Kansas. KETA may also finance projects that extend into other states on the condition that $51 \%$ of the project cost is for facilities located in Kansas. In the case of a project that extends across the state boundary, the KCC must certify that the portion of the project located outside the state will benefit the state.

\section{Activities to Date}

KETA has been actively involved in identifying and supporting electric transmission development in Kansas. After many years during which transmission capacity in Kansas was not significantly expanded or upgraded, the following projects have been proposed or have started construction since KETA began operations:

- WAPA/Eastern Plains Transmission Project. This project consists of 1,000 miles of new transmission lines at a cost of $\$ 1$ billion that is scheduled to be completed by 2010/2011 and would connect two proposed new 700 MW coal-fired power plants in Holcomb, Kansas to the Colorado electric transmission grid. The project consists of an integrated grid of new $500 \mathrm{kV}$ and $345 \mathrm{kV}$ lines throughout Kansas and Colorado, two new substations, and several substation upgrades. As of early 2008, the Kansas portion of the transmission project is in doubt because the Kansas Department of Health and Environment declined to issue a required air quality permit for the proposed Holcomb generation plants based on concerns about carbon dioxide emissions.

- X Plan. A \$419 million project adding two new transmission lines: the SpearvilleMooreland-Oklahoma City $345 \mathrm{kV}$ line and the Wichita-Moorland-Potter City 345 $\mathrm{kV}$ line. SPP and KETA studied the cost-effectiveness of various line configurations related to the X-Plan. In May 2007, KETA expressed interest in the following line segments within Kansas: $345 \mathrm{kV}$ lines from Spearville to Reno and from Spearville to Knoll. ITC Great Plains subsequently announced its intent to construct and operate a new transmission line with capacity of at least $345 \mathrm{kV}$ from Spearville to a new substation in Comanche County and on to an interconnection close to Wichita. This line is equivalent to the Spearville to Reno segment examined by KETA in its initial feasibility study.

- Proposed Kansas Nebraska Plan. This project consists of a new $345 \mathrm{kV}$ line from Spearville north to Knoll and on to Axtell, Nebraska. In August 2007, KETA announced intent to proceed with the Spearville to Knoll to Axtell $345 \mathrm{kV}$ line. During the statutorily required 90 -day period during which private entities may 
formally provide notification of intent to construct the project, ITC Great Plains announced its intent to construct and operate the line. In accordance with its authorizing statute, KETA will monitor ITC's progress on this project.

- Central Kansas Projects. KETA is monitoring the progress of several other transmission improvement projects within central Kansas. As of December 2007, these projects are in various stages of development as listed below:

- Wichita-Reno $345 \mathrm{kV}$ line - KCC granted permits to Westar Energy

- $\quad$ Reno-Summit $345 \mathrm{kV}$ line - KCC granted permits to Westar Energy

- $\quad$ Rose Hill (Kansas) - Sooner (Oklahoma) $345 \mathrm{kV}$ line - Westar Energy has indicated that it intends to build the Kansas portion of this line

- $\quad$ Knoll-S Hays-Heizer $230 \mathrm{kV}$ line - conversion of existing $115 \mathrm{kV}$ line is underway by Midwest Energy. 


\section{NEW MEXICO}

\section{Legislation}

Name: $\quad$ New Mexico Renewable Energy Transmission Authority

Legislation: House Bill 188

http://legis.state.nm.us/sessions/07\%20regular/bills/house/hb0188.html

Date Enacted: March 5, 2007

Governed by: Independent Public Corporation

Administered: Eight-member Renewable Energy Transmission Authority Board

Reports to: Legislature and Governor

Financing Cap: None

Phone: $\quad 505-476-3200$

Fax: $\quad$ 505-476-3220

Web site: $\quad$ http://www.nmreta.org

Contact: $\quad$ Lisa A. Szot, Iszot@nmfa.net

505-992-9627

\section{Summary}

The New Mexico Renewable Energy Transmission Authority (RETA) was created to expand renewable energy transmission and storage projects both within New Mexico and for export. The projects undertaken by RETA must source at least $30 \%$ of their energy from renewable energy sources defined as solar, wind, hydropower, and geothermal; or fuel cells that are not fossil-fueled; and biomass. Biomass is further defined as agriculture or animal waste, small diameter timber, salt cedar and other vegetation from river basins or watersheds in New Mexico, landfill gas, and anaerobic digestion of waste.

RETA is a stand-alone entity administered by an eight-member board. Five members are appointed and serve staggered three-year terms, and three members are government representatives. RETA is authorized to hire staff, make and execute agreements, and enter into partnerships with public or private entities. RETA can also identify and establish corridors for the transmission of electricity within the state; participate in regional transmission forums to plan and negotiate for the creation of interstate transmission corridors; finance or plan, acquire, maintain, and operate eligible facilities; and exercise the power of eminent domain to forward development of its projects, as long as utility property is not taken and electric reliability is not materially diminished as determined by the New Mexico Public Regulation Commission.

RETA can also enter into contracts for leasing RETA-owned facilities, as long as the revenue is deposited into a renewable-energy transmission bonding fund. RETA can also enter into contracts to lease or operate transmission facilities that are owned by other parties. RETA can issue revenue bonds to finance projects and collect payments from the use of eligible facilities to finance payment of the revenue bonds. Finally, RETA may borrow money and mortgage and pledge any leases, loans, or contracts entered into by RETA. 
RETA must provide an annual report to the Governor and the Legislature by December $1^{\text {st }}$ of each year. RETA issued its first report in 2007. In addition, the New Mexico Finance Authority Oversight Committee monitors and oversees RETA. The Committee will review and provide assistance and advice to RETA on proposed projects. RETA is required to provide financial reports to the Committee on a quarterly basis. The Committee will meet regularly to review statutes, constitutional provisions, regulations and court decisions governing energy transmission and renewable energy development and will annually report its findings and any recommended changes or legislation to the Governor, the New Mexico Public Regulation Commission, and the Legislature by December $15^{\text {th }}$ of each year.

\section{Organization Size and Structure}

RETA is governed by an eight-member board. Three members are appointed by the Governor; one member is appointed by the New Mexico Speaker of the House of Representatives; and one member is appointed by the President Pro Tempore of the New Mexico Senate. Three additional members are state officials: the State Treasurer or designee, the State Investment Officer or designee, and the Secretary of the Energy, Minerals, and Natural Resources Department Cabinet Secretary, with the Secretary acting as a non-voting member.

The members of the board are expected to be knowledgeable on renewable energy development and the electric industry. One of the Governor's appointed board members should have a background in the financing of electric transmission projects. In no case is a board member to represent anyone that owns or operates facilities.

On August 21, 2007, the Governor announced the following board member designations:

- Robert E. Busch, Public Service Enterprise Group Services Corp. (retired), Chair

- Ned Farquhar, Natural Resources Defense Council (NRDC)

- Steven S. Michel, Western Resource Advocates

- Beatriz (Betty) Rivera, Energy Resource Associates LLC

- Robert (Bob) McNeil, El Paso Electric Co. (retired)

- State Treasurer James Lewis or his designee Mark Valdez

- State Investment Officer or his designee Paul Blanchard

- Joanna Prukop, Energy, Minerals and Natural Resources Cabinet Secretary (ex officio), Secretary

RETA is authorized to hire staff as required. In December 2007, RETA announced that Lisa Szot, former executive at BP, had accepted the position of Executive Director.

Ms. Szot will be assessing RETA's administrative needs and hiring any required staff later in 2008 .

\section{Eligible Technologies and Applications}

RETA may only sponsor electric transmission infrastructure projects that have at least 30\% of the energy sourced from renewables. Eligible resources include solar, wind, 
hydropower, geothermal, fuel cells that are not fossil fueled, biomass resources

(agricultural waste, animal waste, small diameter timber, salt cedar and other phreatophyte or woody vegetation removed from river basins or watersheds), landfill gas, and anaerobically digested waste biomass. RETA can also fund clean energy storage projects, such as compressed air storage for wind power. Any projects related to or affecting in-state retail electricity supply or reliability must first be approved by the New Mexico Regulation Commission.

\section{Funding and Financing}

RETA has received a \$1 million general fund appropriation as start-up money for 2007 and 2008. RETA may issue and sell revenue bonds, known as Renewable Energy Transmission Bonds. These bonds are payable solely from the Renewable Energy Transmission Bonding Fund. The net proceeds from the bonds are to be used by the authority for financing or acquiring eligible facilities. Renewable Energy Transmission Bonds are exempt from New Mexico state or local taxes.

The Renewable Energy Transmission Bonding Fund was established to receive revenues collected by RETA from operating or leasing eligible facilities; fees and service charges; and, if the authority has provided financing for eligible facilities, payments of principal and interest on loans. Currently, no financing cap has been established for RETA. RETA may issue and sell bonds to refund outstanding renewable energy transmission bonds, through public or private sale, if RETA considers it to be in the interest of the state.

RETA is prohibited from pursuing a project that utilities or other entities are implementing or performing. Before committing to a project, RETA must provide notice to each New Mexico utility and the New Mexico Public Regulation Commission, as well as make information available on RETA's Web site and publish a notice in a newspaper of general circulation in New Mexico and in a newspaper where the RETA's proposed facility would be located. The notice must describe RETA's proposed project, the existing or expected renewable energy sources, the names of all people that are or will develop and/or own the renewable energy sources, the peak output capacity, source type, location, and expected online date of the renewable energy sources. A challenge may be filed to RETA's determination that eligible facilities are involved, and RETA is required to hold a public hearing no later than 30 days after receiving the challenge. After the hearing, RETA rules on eligibility, and that ruling is subject to appeal to the New Mexico District Court.

Following 90 days from a notice by RETA or from RETA's determination of eligibility, an entity may express intent to pursue the project. That entity has 12 months to demonstrate progress towards developing the project. Actively pursuing federal, state, local, or private permits is considered progress under the 12-month timetable, as long as pursuit of those permits is ongoing. If no interest or progress is demonstrated, RETA may move forward with the project.

RETA is not allowed to own or control facilities unless:

- They are leased to a public utility or other entity approved by the New Mexico Public Regulation Commission 
- The operation, maintenance, and use of the facilities are by a public utility or other entity approved by the New Mexico Public Regulation Commission

- RETA owns or controls the facilities for not over 180 days after the end of a leasing or operations and maintenance contract or RETA gains possession as a result of a breach of contract or bankruptcy procedures

- The facilities do not affect in-state retail rates or electric reliability.

Electric utilities may recover costs of a transmission project under the New Mexico Renewable Energy Transmission Authority Act if the transmission project has received a certificate of public convenience and necessity from the New Mexico Public Regulation Commission, if the costs are considered prudent and if the project is determined to be used and useful. Municipal utilities not subject to regulation by the New Mexico Public Regulation Commission can recover costs if the municipal utility's governing body grants approval.

\section{Activities to Date}

RETA released its first annual report for 2007. The report outlines the discussions conducted at the three board meetings held in October, November, and December. The report notes that public comments have been very informative especially from New Mexico ranchers who are struggling to find ways to decide amongst the many competing wind development offers they receive on their lands. The difficulty arises from a lack of knowledge concerning future transmission availability. The ranchers hope RETA will be able to provide a picture of transmission plans in the region that could deliver wind development on their lands to markets. The report also mentions that the RETA board had avoided making any major expenditures in anticipation of the Executive Director coming on board. With the new Executive Director on board, RETA is developing criteria for assessing projects that are brought forward for review along with working closely with stakeholders and the public on designating corridors in New Mexico.

RETA is contemplating joining the High Plains Express Project, which is developing a high voltage system from northeast Wyoming heading south through eastern Colorado to New Mexico and Arizona. The parties currently involved with this project are Trans-Elect, WAPA, Salt River Project, PNM, Xcel Energy, Colorado Springs Utilities, Platte River Power Authority, Tri-State Generation and Transmission Association, the Colorado Clean Energy Development Authority, and the Wyoming Infrastructure Authority. Phase I, consisting of preliminary engineering and economic studies, was completed in early 2008 and showed positive benefits arising from the project. As a result, the project has moved on to Phase II, the development stage, consisting of defining the project, ownership negotiations, studies on siting and economics, review of commercial issues, and addressing regulatory and policy issues. The project consists of two $500 \mathrm{kV}$ lines with 3,500 MW of capacity connecting four other transmission projects already under development into an integrated grid. These other projects are the Wyoming-Colorado Intertie, Eastern Plains Transmission Project, SunZia, and a New Mexico wind collector project. The project is expected to cost $\$ 5.13$ billion. 


\section{NORTH DAKOTA}

\section{Legislation}

$\begin{array}{ll}\text { Name: } & \text { North Dakota Transmission Authority } \\ \text { Legislation: } & \begin{array}{l}\text { House Bill No. } 1169 \\ \text { http://www.legis.nd.gov/assembly/59-2005/bill-text/FRAB0300.pdf }\end{array} \\ \text { Date Enacted: } & \text { January 4, 2005 } \\ \text { Governed by: } & \text { North Dakota Industrial Commission } \\ \text { Administered: } & \text { Sandi Tabor, Acting Director } \\ \text { Reports to: } & \text { North Dakota Department of Agriculture } \\ \text { Financing Cap: } & \text { \$800 million } \\ \text { Phone: } & 701-328-3722 \\ \text { Fax: } & 701-328-2820 \\ \text { Web site: } & \text { None } \\ \text { Contact: } & \text { ndda@nd.gov }\end{array}$

\section{Summary}

The North Dakota Transmission Authority (NDTA) is intended to diversify and expand the North Dakota economy by facilitating development of transmission in support of the production, transportation, and consumption of electricity sourced in North Dakota. NDTA is part of the North Dakota Industrial Commission and can (among other things):

- Offer grants or loans and provide other forms of financial assistance

- Execute contracts

- Borrow money and issue bonds

- Accept aid, grants, or contributions

- Plan, finance, develop, acquire, own in whole or in part, lease, rent, and sell or divest electric transmission facilities

- Enter into contracts to construct, maintain, and operate electric transmission facilities

- Investigate, plan, prioritize, and propose corridors for electricity transmission

- Confer with the North Dakota Public Service Commission, other state or federal authorities, and/or regional transmission organizations

- Work to establish rates, fees, or tariffs for transmission facilities and service offered by the NDTA, in consultation with and subject to the approval by the North Dakota Public Service Commission.

Any transmission facilities financed and/or constructed by NDTA are exempt from property taxes for up to five years. After five years, transmission facilities over $230 \mathrm{kV}$ are still exempt from property taxes but are taxed at a per-mile rate. 


\section{Organization Size and Structure}

NDTA is a part of and governed by the North Dakota Industrial Commission. Sandi Tabor is the Acting Director.

\section{Eligible Technologies and Applications}

The NDTA is limited to electric transmission facilities.

\section{Funding and Financing}

NDTA is a part of the North Dakota Industrial Commission and works under the Commission budget. With prior authorization from the Industrial Commission, NDTA may issue revenue bonds up to a maximum of $\$ 800$ million. The bonds are payable from revenues received by the NDTA from transmission facilities, services and activities, and do not constitute a debt of the state. NDTA may also accept loans and grants, and establish and maintain a reserve fund. NDTA does not receive a fiscal appropriation from the North Dakota Legislature; financing comes from the revenue bonds that NDTA issues.

Before constructing a facility itself, NDTA is required to advertise the project and request submissions of notice of intent from other entities. Other organizations have 180 days to submit a notice of intent to build the facility. The NDTA may require a bond, a development plan, and a timetable. If no notices are received, then NDTA can proceed with the project itself. If such a notice of intent is received, the NDTA can still proceed if it decides doing so is in the public interest, based on economic impact to the state, economic feasibility, technical performance, reliability, past performance, and the probability of successful competition and operation.

NDTA views itself as a developer of last resort, but is allowed to own or partly own transmission facilities, though it must sell its ownership as soon as economically prudent. Before taking ownership, the NDTA must develop a plan that documents the public purpose of owning a transmission facility, the circumstances where ownership by the NDTA is no longer required, and a plan to sell the NDTA's ownership as soon as economically feasible.

\section{Activities to Date}

The NDTA has focused on outreach and learning about transmission obstacles in North Dakota. The NDTA also has been working to develop transmission plans with project participants in Lignite Vision 21, an organization formed to consider and develop lignite power plants in North Dakota. The NDTA also has participated in the Upper Great Plains Transmission Coalition, a consortium of wind and coal interests, and has filed comments at FERC regarding the Midwest ISO's transmission cost recovery mechanisms. The NDTA is also working to incorporate North Dakota into the Minnesota utilities' CapX 2020 transmission planning process. The NDTA said it is interested in acting more as a facilitator for encouraging private industry investment in transmission. 
On April 12, 2007, the North Dakota Industrial Commission announced that the Bank of North Dakota would be providing \$25 million of the \$33 million needed towards a new transmission line being built by Basin Electric Power Cooperative. The project consists of a new 67-mile long $230 \mathrm{kV}$ line from an existing substation near Belfield to a proposed new substation near Rhame, in southwest North Dakota. NDTA facilitated the Bank of North Dakota's decision to participate in this project by brokering the deal with Basin Electric. Basin has plans for a second transmission line that it may also ask for assistance from NDTA and the Bank of North Dakota. The line would run from the Antelope Valley generating plant near Beulah to Tioga. 


\section{SOUTH DAKOTA}

\section{Legislation}

Name:

Legislation:

Date Enacted:

Governed by:

Administered:

Reports to:

Financing Cap:

Phone:

Fax:

Web site:

Contact:
South Dakota Energy Infrastructure Authority

South Dakota Codified Laws Chapter 1-161 (2005)

http://www.sdeia.com/PDF/SDEIALegislativelanguage.pdf

2005 Legislative Session

Independent Public Corporation

Five-member board

Department of Tourism and State Development

$\$ 1$ billion

$605-773-3301$

605-773-3256

http://www.sdeia.com

Hunter Roberts, hunter.roberts@state.sd.us

\section{Summary}

The South Dakota Energy Infrastructure Authority (SDEIA) was created to facilitate the development of energy production facilities and energy transmission facilities both inside South Dakota and outside the state. SDEIA is a separate stand-alone entity that may (among others things):

- Make and execute contracts, borrow money, and issue bonds

- Employ engineers, attorneys, and other consultants and employees

- Contract with agencies of the state to provide staff and support services

- Make loans and grants, and enter into financing agreements with any governmental agency or any person for the costs incurred in connection with the development, construction, acquisition, improvement, maintenance, and operation of decommissioning of electric transmission facilities.

SDEIA may finance, construct, develop, maintain, operate, and decommission new or upgraded transmission facilities. That said, SDEIA is not designed to own and/or operate transmission facilities, but to facilitate the development of transmission infrastructure by other parties. SDEIA can establish fees, rates, tariffs, or other charges for the use of its facilities and for all services it renders, but must consult with the Public Utilities Commission and any other relevant governmental authority prior to doing so. SDEIA also has the authority to investigate, plan, prioritize, and establish transmission corridors and may enter into partnerships with public or private entities to develop and operate transmission facilities. SDEIA may lease, rent, or own transmission facilities, although it must divest ownership of any transmission facility as soon as economically practicable, defined as recovery of SDEIA's net investment.

SDEIA is also required by statute to help entities that wish to develop new, or upgrade existing, transmission lines through designing a business plan and identifying potential financing options. SDEIA must also help other state transmission infrastructure authorities 
and federal or regional entities that wish to develop new, or upgrade existing, transmission lines to transmit generation to, from, or within South Dakota.

\section{Organization Size and Structure}

SDEIA named Hunter Roberts as Executive Director in April 2007. SDEIA is governed by a five-member board appointed by the Governor and serving staggered six-year terms. The board members as of August 2007 are:

- Mike Trykoski, Rushmore Professional Services

- Kyle White, Black Hills Corp.

- Audry Ricketts, South Dakota Rural Electric Association

- Mike Held, South Dakota Farm Bureau

- Dr. Mike Ropp, South Dakota State University

\section{Eligible Technologies and Applications}

The legislative language suggests that SDEIA could support any "energy production facilities" and "energy transmission facilities". The Authority has, at this time, chosen to limit the scope of their activities to electricity. South Dakota is working to develop its electricity generation resources; therefore a significant portion of SDEIA's activity is focused on bringing this generation to market.

\section{Funding and Financing}

Initially, funds were transferred from the Department of Tourism and State Development, and staff were on loan. The legislature subsequently approved a total of $\$ 247,000$ in funding for 2006 and 2007, and \$56,000 for 2008. The legislation gives SDEIA the ability to issue revenue bonds to finance the development or ownership of facilities, up to a maximum of $\$ 1$ billion, but the bonds must first be approved by the Legislature. SDEIA can enter into partnerships and own or partially own energy facilities but is required to divest itself of ownership at the first economically sound opportunity. The authority can invest funds not needed immediately in (among other things) bonds, notes, treasury bills, certificates of deposit, and obligations issued by any state.

\section{Activities to Date}

Originally, the SDEIA was required to meet annually with any interested transmission owner or generator to determine the need for generation or transmission in South Dakota and to evaluate how SDEIA may help with these endeavors. The SDEIA then had to submit a report by December $1^{\text {st }}$ each year to the Governor, the Legislature, and the South Dakota congressional delegation outlining how to stimulate generation in South Dakota and transmission to, from, and within the state, based on the interviews. The SDEIA also had to annually review state and federal laws and rules affecting generation and transmission and make recommendations for improvements to the Governor, Legislature and the congressional delegation. In early 2008, the Legislature passed Senate Bill 54, amending SDEIA's annual interview report requirement. SDEIA is now required to submit 
interview reports at least every five years, though the authority can choose to do so more frequently. This change was made at SDEIA's request and the Authority feels that the legislative change will give them more flexibility in their future efforts.

SDEIA has conducted several studies since its inception, and a summary of these studies is provided below.

\section{Joint Report of the South Dakota Energy Infrastructure Authority and South Dakota} Energy Task Force (December 2005)

Citing similar reporting requirements (the Task Force was given the goal of examining energy resources and transmission issues) the SDEIA and the South Dakota Energy Task Force combined their resources and issued a joint report. The report examined in depth the transmission system in South Dakota, specifically the issues of transmission reliability, transmission constraints, federal requirements, and the operations of the Midwest Independent System Operator. The report identified potential markets for power generated in South Dakota, noting the state had facilities in both the Eastern and Western Interconnections. The report identified a need for both baseload and renewable power that could be developed and exported to load centers in both directions, and identified the transmission infrastructure upgrades required to transport that power to market.

\section{Project Report: Results of Industry Interviews (November 2006)}

This report summarized a series of interviews conducted by Schulte Associates LLC on behalf of SDEIA. The original legislation (Chapter 1-161) required SDEIA to conduct interviews with entities that produce, transmit, distribute, regulate, control and market electricity in South Dakota. Schulte Associates was contracted to conduct these interviews and gain input on potential projects for increasing electric power generation in South Dakota; enhancements needed to transmit electricity; and activities the state and SDEIA could undertake to assist in developing the above. The interviewees noted that South Dakota has significant wind resources that could be marketed to other states, but the needed transmission was lacking. In particular, the report highlights the 'seams' issue, where parts of South Dakota are in the Midwest ISO but large portions are not, and while transmission development has been occurring within the Midwest ISO areas, these are not connecting to areas outside the Midwest ISO footprint.

\section{Project Report: Energy Study (January 2007)}

Also conducted by Schulte Associates LLC on behalf of SDEIA, the study examines options for developing coal-, nuclear-, and wind-energy generating facilities in South Dakota specifically for the purpose of exporting power to other states. The report describes two coal-based technologies and notes there are no coal mines in South Dakota and no major rail line routes to bring coal into the state, making construction of baseload coalfired units costlier than in other regions. The report examines four potential nuclear technology options and advises that a nuclear power plant in South Dakota would be a 'greenfield' site entailing significant extra costs associated with siting and permitting, and additionally, nuclear plants require large bulk power transfer capacity, something currently 
lacking in the state. The study concludes that wind energy offers the greatest potential for development in South Dakota, estimating 12,000 MW of wind energy could be developed and exported as long as adequate transmission was made available.

\section{South Dakota Wind Power Report (December 2007)}

This report was created by SDEIA to identify the issues surrounding wind power development in South Dakota and to address concerns that South Dakota is not doing enough to develop wind energy. The report is the result of information gathered from interviews that SDEIA conducted with developers, electric power entities, and government agencies during the summer of 2007. It is intended to serve as a resource document for government officials and the public to provide guidance on decision-making and does not make any specific recommendations respecting wind development. The report notes that the National Renewable Energy Laboratory (NREL) estimates of South Dakota wind capacity could provide for over $50 \%$ of U.S. electricity demand. But SDEIA points out that a lack of transmission capacity and the large distances and difficulties involved in connecting this amount of wind to the grid makes reaching such a goal unfeasible. Nearterm wind development will focus on transmission into Minnesota and points east. South Dakota would like to be able to move wind energy west into the Colorado system but there is a very limited amount of transmission connection with the Western grid. The report also contains extensive discussions on the technical aspects of wind development, the costs and benefits to developers and to the state, and tax and regulatory considerations. 


\section{WYOMING}

\section{Legislation}

Name:

Legislation:

Amendment:

Date Enacted:

Date Amended:

Governed by:

Administered:

Reports to:

Financing Cap:

Phone:

Fax:

Website:

Email:

Contact:
Wyoming Infrastructure Authority

Senate File No. SF0052, 04LSO-0089

http://legisweb.state.wy.us/2004/engross/SF0052.pdf

HB NO. 0129

http://legisweb.state.wy.us/2006/Introduced/HB0129.pdf

June 2004

June 2006

Independent State Instrumentality

Five-member Board of Directors

Wyoming Legislature and Governor

$\$ 1$ billion for private activity, no cap for WIA-owned investments

$307-635-3573$

$307-635-5336$

http://www.wyia.org/

info@wyia.org

Steve Waddington, Executive Director, stevew@wyia.org

\section{Summary}

The Wyoming Infrastructure Authority (WIA) was established by legislation in 2004 and was the first state transmission infrastructure authority. The statute creating the WIA states that the purpose of creating the Wyoming Infrastructure Authority is to "diversify and expand the Wyoming economy through improvements in the state's electric transmission infrastructure and to facilitate the consumption of Wyoming energy by planning, financing, constructing, developing, acquiring, maintaining, and operating electric transmission facilities and related supporting infrastructure and undivided or other interest therein to facilitate the transmission of energy." WIA is a state instrumentality governed by a five-member board appointed by the Governor serving staggered four-year terms.

WIA can employ staff; make contracts; receive gifts or grants; plan, finance, construct, maintain and operate within and outside the state, property, structures, equipment, facilities and works of public improvement; and enter into partnerships with public and private entities. WIA may also plan and establish electric transmission corridors and acquire by condemnation any properties necessary for the development of transmission infrastructure. WIA can borrow money and issue revenue bonds to finance projects.

In 2006, a legislative amendment expanded WIA's scope to include advanced coal technology and energy technology facilities. WIA's authority now includes the facilities and related supporting infrastructure for advanced technologies utilizing coal for production and transmission of electricity. Therefore, unlike some of the other transmission infrastructure authorities profiled, WIA can finance, construct, or develop certain electric production facilities as well as transmission facilities. 
WIA sees itself as having two primary roles: 1.) a promoter and facilitator of transmission projects, and 2.) a participant in the planning, development, and financing of transmission projects. WIA plans on being the lead party in the early planning and development of transmission projects, but has an exit plan should a transmission project prove commercially viable without WIA's involvement. WIA looks to enter into public-private partnerships to promote specific project initiatives, and then to exit a project once the project has been financed and WIA recovers its fees (with interest).

WIA defines four stages for each transmission project, with WIA being involved in at least the first two stages. The first stage is a feasibility assessment and includes selecting project partners, identifying and meeting with prospective generators and other customers of the project, addressing public policy issues relating to the project, building public support for the project, addressing administrative and regulatory issues pertaining to the project, and determining the business structures, legal documentation, and budgets required to complete the project.

The second stage focuses on development and encompasses identifying and obtaining project permits, performing engineering, studying options for project cash flows, including project revenues and cost recovery, initial development of the financial model for the project, initial arrangement of the financing for the project, and finalizing and creating the business structures required to complete the project.

The third stage is aimed at financing and final project development and entails finalizing agreements to provide transmission services, finalizing the financing of the project and the project schedule, acquiring rights-of-way necessary for the project, selecting the contractor for the project, and issuing requests for proposals for other project contractors. Assuming the financing is finalized, WIA envisions exiting the project at this stage. The fourth stage is focused on project construction until commercial operation.

\section{Organization Size and Structure}

WIA is governed by a five-member board appointed by the Governor serving staggered four-year terms. The statute creating the WIA also called for the creation of a five-member advisory board. WIA is authorized to hire staff as needed and currently has three staff members. The staff and board as of February 2008 are listed below.

WIA Staff:

- Steve Waddington, Executive Director

- Holly Martinez, Administrative Manager

- Loyd Drain, Development Director

Board:

- Mike Easley, (Chairman), Powder River Energy Corp.

- Kyle White (Vice-Chair), Black Hills Power Corp.

- Bryce Freeman, (Treasurer \& Secretary), Wyoming Office of Consumer Advocate

- Donald O'Shei, TriLateral Energy LLC

- TBD 


\section{Eligible Technologies and Applications}

The Act originally limited WIA to electric transmission infrastructure, but the 2006 amendment expanded WIA's scope to projects dealing with energy rather than just electrical energy. Theoretically, WIA could become involved with all types of energy infrastructure development. However, the intent was to expand the WIA role to include the promotion of advanced technologies to utilize coal for electricity production. Wyoming has abundant coal reserves and excellent untapped wind power resources. A driving factor in the creation of WIA was to facilitate the development of coal and wind resources and provide access to markets for new Wyoming generation, particularly into California and the Southwest.

\section{Funding and Financing}

WIA has been generally supported and well funded by the Wyoming Legislature. All funding from the legislature is from the general fund in the form of loans. In the initial legislation, WIA was authorized an appropriated loan of $\$ 250,000$ for start-up operations. For the fiscal year starting July 2005 , a budget of $\$ 6.6$ million was approved with $\$ 1.6$ million earmarked for operations and $\$ 5$ million established in a development fund for transmission development, feasibility studies, permitting and siting costs, and engaging potential private industry partners. For 2007/2008, WIA has a \$1.6 million operating budget and an increase in the development account to $\$ 10$ million. Funds from the development account are released subject to a proposed project, an economic benefit report, and the approval of the Wyoming State Loans and Investments Board (SLIB) ${ }^{\mathrm{x}}$. So far, $\$ 2$ million has been released from the loan fund and is being deployed in development activities.

WIA has the authority to create and issue revenue bonds through resolutions of the Board. These bonds are obligations of WIA and do not constitute obligations of the state. WIA can collect revenues from the operation of any facilities it owns and the bonds are payable only from this revenue. WIA can extend its bonding capability to the private sector for infrastructure investments, subject to a maximum outstanding amount of bonds of $\$ 1$ billion. ${ }^{\mathrm{y}}$ WIA can also borrow funds and accept grants, and it can mortgage and lease or sublease any of its facilities.

Prior to going forward with a project, WIA is obligated to provide public notice and give other entities 30 days to indicate intent to take over the project. The proponent then has 180 days to start the project. If neither of these conditions is met, WIA may proceed with the project itself.

\footnotetext{
${ }^{\mathrm{x}}$ The five state-wide Wyoming elected officials comprise the SLIB.

${ }^{\mathrm{y}}$ This cap is not applicable to bonds issued for facilities owned by WIA; however, it is unlikely that WIA will own facilities to any measurable degree.
} 


\section{Activities to Date}

WIA has been very active since its creation in 2004. The following is a list of projects currently in progress.

- Hughes Transmission Project. In September 2005, WIA did a private placement of bonds to the Wyoming State Treasurer, amounting to $\$ 34.5$ million. The proceeds financed three-quarters of the costs of a transmission line being constructed by Basin Electric Power Cooperative of Bismarck, North Dakota. WIA will receive a transaction fee of $0.125 \%$ amounting to $\$ 43,125$ per year and decreasing over time as the principal loan amount is paid off. All told, WIA expects to receive about $\$ 600,000$ over the 20 -year term of the contract. The project is a 130 -mile, $230 \mathrm{kV}$ transmission line connecting the Hughes substation, north of Rozet, to the Carr Draw substation, west of Gillette and a proposed substation north of Sheridan.

- TransWest Express. WIA has partnered with the Arizona Public Service (APS) and National Grid to develop a transmission line from the Powder River Basin to Phoenix, to enable 3,000 MW of new Wyoming coal and wind generation to reach the Desert Southwest. The participants are currently in the midst of a four-year plan to invest about $\$ 100$ million to design and engineer the line and secure all necessary permits and routing rights-of-way. WIA has a $10 \%$ stake in the project and will be reimbursed with interest should the project receive financing.

The TransWest Express line has some overlap with the Gateway South line proposed by PacifiCorp that would extend from Wyoming into Utah and into the Desert Southwest. In August 2007, WIA entered into an interim agreement with APS, National Grid, and PacifiCorp to co-develop the Gateway South and TransWest Express lines, with a decision on next steps to be made in 2008. National Grid will be the lead developer for co-development of both lines, with active participation from WIA, APS, and PacifiCorp.

- Wyoming Colorado Intertie Transmission Project. WIA has partnered with TransElect and the Western Area Power Administration (WAPA), aiming to expand transmission capacity across the constrained path referred to as TOT3 between Wyoming and Colorado. Siemens/PTI completed an initial planning study for the project. The study considers a number of different configurations for the project and indicates that 800 to $900 \mathrm{MW}$ can be transferred from Wyoming to Colorado by building a $345 \mathrm{kV}$ line. The line is slated to interconnect to the Pawnee substation in Public Service of Colorado's service territory, which corresponds to one of the proposed energy zones under Colorado's recently enacted renewable energy zone legislation.

An open season to allocate transmission capacity will be held in summer 2008 and, depending on the market response, the proposed transmission line could be double-circuited to allow more generation to be put on the line. The line could be developed in two phases, with the first phase accessing wind generation in 
Wyoming and terminating near the Laramie River Station, near Wheatland, and a second phase including base load and/or load-leveling facilities and additional wind generation. If the open season is successful, operation of the line could begin by mid-2013.

- High Plains Express. WIA is participating with several other parties in developing a high voltage system from northeast Wyoming heading south through eastern Colorado to New Mexico and Arizona. Additional companies participating include Trans-Elect, WAPA, Salt River Project, PNM, Xcel Energy, Colorado Springs Utilities, Platte River Power Authority, Tri-State Generation and Transmission Association, and the Colorado Clean Energy Development Authority. The New Mexico Renewable Energy Transmission Authority is contemplating joining the project. Phase I consisted of preliminary engineering and economic studies, and was completed in early 2008. Phase I showed positive benefits arising from the project. As a result, the project has moved on to Phase II, the development stage, consisting of defining the project, ownership negotiations, studies on siting and economics, review of commercial issues, and addressing regulatory and policy issues. The project consists of two $500 \mathrm{kV}$ lines with 3,500 MW of capacity connecting four other transmission projects already under development into an integrated grid. These other projects are the WyomingColorado Intertie, Eastern Plains Transmission Project, SunZia, and a New Mexico wind collector project. The project is expected to cost $\$ 5.13$ billion.

- Wyoming-West Project. WIA, in partnership with National Grid and WAPA, conducted a feasibility study on transmitting nearly 7,000 MW of Wyoming generation south to Nevada and California. The feasibility study examined corridor availability for a $345 \mathrm{kV}$ and a $500 \mathrm{kV}$ line option from southwest Wyoming through Utah or Nevada and possibly extending to California. A rightof-way application was filed with the U. S. Bureau of Land Management. The feasibility study, completed in 2007, resulted in the project being placed on hold in favor of devoting resources to the TransWest Express and Gateway South projects, which perform a similar function.

- Clean Coal Gasification Plant. WIA partnered with PacifiCorp to conduct feasibility studies on three different clean coal power plant technology options for a potential integrated gasification combined-cycle plant near Point of Rocks, Wyoming. In January 2008, PacifiCorp announced they had completed the feasibility studies and found the technology to be too expensive to implement at this time. As a result, the project has been put on hold. 


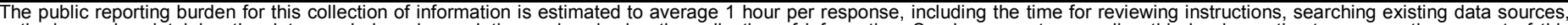

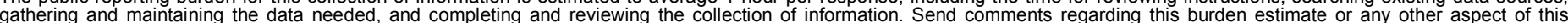

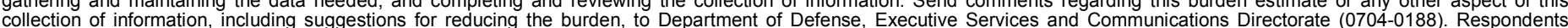

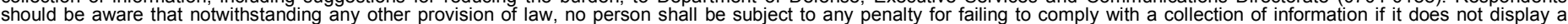

should be aware that notwithstanding

PLEASE DO NOT RETURN YOUR FORM TO THE ABOVE ORGANIZATION.

\section{REPORT DATE (DD-MM-YYYY) \\ May 2008 \\ 2. REPORT TYPE \\ Subcontract report}

4. TITLE AND SUBTITLE

State Transmission Infrastructure Authorities: The Story So Far
3. DATES COVERED (From - To) December 2007 - December 2008

5a. CONTRACT NUMBER

DE-AC36-99-GO10337

5b. GRANT NUMBER

5c. PROGRAM ELEMENT NUMBER

5d. PROJECT NUMBER

NREL/SR-500-43146

5e. TASK NUMBER

WER85001

5f. WORK UNIT NUMBER

7. PERFORMING ORGANIZATION NAME(S) AND ADDRESS(ES)

Exeter Associates, Inc.

5565 Sterrett Place, Suite 310

8. PERFORMING ORGANIZATION REPORT NUMBER

Columbia, MD 21044

LAM-8-77548-01

9. SPONSORING/MONITORING AGENCY NAME(S) AND ADDRESS(ES)

National Renewable Energy Laboratory

1617 Cole Blvd.

Golden, CO 80401-3393

10. SPONSOR/MONITOR'S ACRONYM(S)

NREL

11. SPONSORING/MONITORING AGENCY REPORT NUMBER NREL/SR-500-43146

12. DISTRIBUTION AVAILABILITY STATEMENT

National Technical Information Service

U.S. Department of Commerce

5285 Port Royal Road

Springfield, VA 22161

13. SUPPLEMENTARY NOTES

NREL Technical Monitor: David Corbus

14. ABSTRACT (Maximum 200 Words)

This report examines the status and future direction of state transmission infrastructure authorities. It summarizes common characteristics, discusses current transmission projects, and outlines common issues the state infrastructure authorities have faced.

\section{SUBJECT TERMS}

transmission; state transmission infrastructure authorities; Western Governors' Association; wind power

16. SECURITY CLASSIFICATION OF:
\begin{tabular}{|l|l|l|}
\hline a. REPORT & b. ABSTRACT & c. THIS PAGE \\
Unclassified & Unclassified & Unclassified \\
& & \\
\hline
\end{tabular}

\begin{tabular}{l|l}
$\begin{array}{l}\text { 17. LIMITATION } \\
\text { OF ABSTRACT }\end{array}$ & $\begin{array}{l}\text { 18. } \\
\text { NUMBER } \\
\text { OF PAGES }\end{array}$ \\
UL & \\
& \\
\end{tabular}

19a. NAME OF RESPONSIBLE PERSON

19b. TELEPHONE NUMBER (Include area code) 